\title{
LOS HERMANOS BERRIO: CAPITAL MORISCO, MEDIACIÓN POLÍTICA Y TRANSFORMACIONES COMUNITARIAS*
}

\author{
Rafael M. Pérez García y Manuel F. Fernández Chaves**
}

\section{INTRODUCCIÓN}

El presente artículo supone una aplicación práctica del planteamiento general de investigación en relación con las élites moriscas que proponemos en el trabajo monográfico que lleva por título Las élites moriscas entre Granada y el Reino de Sevilla. Rebelión, castigo y supervivencias. En estas páginas, atendiendo a las continuidades existentes en la historia de los moriscos granadinos entre los periodos anterior y posterior a la guerra de 1568-1570, hemos querido estudiar el protagonismo de los mercaderes del Albaicín de Granada en el devenir político de su comunidad, detectando la existencia de un capital morisco de relevancia que jugó un papel determinante en el mismo. En concreto, hemos centrado nuestra atención en la familia de los Berrio, cuya importancia fue apuntada hace mucho tiempo por el propio Bernard Vincent ${ }^{1}$ y recientemente tratada de manera singularizada en un breve pero brillante estudio ${ }^{2}$. En todo

* Este trabajo se ha realizado gracias a una Ayuda a la Investigación para Temas Mudéjares del Centro de Estudios Mudéjares de Teruel. La labor científica de sus autores se inscribe en el marco del Departamento de Historia Moderna de la Universidad de Sevilla, del Proyecto de Excelencia "En los orígenes de la Andalucía multicultural. Integración y rechazo de los moriscos (Reinos de Córdoba y Sevilla, siglos XVI y XVII)", P07-HUM-2681, financiado por la Consejería de Innovación, Ciencia y Empresa de la Junta de Andalucía, y del Proyecto I+D “Los últimos moriscos. Pervivencias de la población de origen islámico en la Andalucía de los siglos XVII y XVIII" (HAR-2009-07267), financiado por el Ministerio de Ciencia e Innovación. Agradecemos al profesor William Childers su generosidad al habernos cedido numerosos documentos relativos a los hermanos Berrio, fruto de su investigación.

** Universidad de Sevilla.

1. A. Domínguez ortiz y B. Vincent, Historia de los moriscos. Vida y tragedia de una minoría, Madrid, Alianza, 1979, 1985, p. 61.

2. B. VINCENT, «Les frères Berrio, marchands morisques grenadins» en R. Franch BENAVENT y R. Benítez SÁnchez-Blanco (eds.), Estudios de Historia Moderna en Homenaje a la profesora Emilia Salvador Esteban, Valencia, Universidad de Valencia, 2008, vol. II, pp. 923-926. 
este proceso, la ciudad de Sevilla, objeto de nuestro interés historiográfico ${ }^{3}$, fue un enclave de primer orden, a pesar de que todavía no estén plenamente precisadas sus funciones específicas dentro de la malla de los intereses y estrategias puestas en marcha por los líderes moriscos. En este trabajo, nuevamente, hemos querido hacer hincapié en la naturaleza de Sevilla como nodo de primer orden dentro de las redes peninsulares de los moriscos granadinos, al mismo nivel que centros como Pastrana, Toledo y Granada.

\section{LOS BERRIO EN GRANADA (C. 1530-1569): FAMILIA, SITUACIÓN SOCIAL, NEGOCIOS Y PATRIMONIO \\ LAS RELACIONES FAMILIARES EN GRANADA}

Los orígenes familiares de los hermanos Lorenzo [Pérez] de Berrio y Melchor de Berrio nos siguen resultando desconocidos. Parece claro que Lorenzo era el hermano mayor, puesto que desempeñaba un patente papel directivo en los negocios, y en los documentos de su época granadina sistemáticamente se le menciona delante de su hermano; más aún, durante bastantes años aparece él solo en las operaciones económicas. Melchor, por su parte, habría nacido hacia $1532^{4}$. A comienzos de los años cincuenta ya los documentamos haciendo negocios $^{5}$, y desarrollan una importante actividad mercantil durante toda esta década, aunque una investigación sistemática en los protocolos notariales granadinos seguramente adelantaría esta situación unos años atrás. Es posible que el principal enlace familiar que conocemos de estos hermanos guarde relación con sus intereses económicos. Así, Lorenzo Pérez de Berrio contrajo matrimonio con Elena Sánchez Zinetia, la hija del rico mercader Daniel Sánchez Zinety, quien en su testamento de 1563 afirma haberle dado en dote la respetable cantidad de 2.000 ducados, además de hacerle testamentario suyo junto con su hijo Sebastián Suárez el Zinety ${ }^{6}$. Aunque ignoramos la fecha en que se casó Lorenzo de Berrio, el censo de Granada de 1561 ya lo recoge viviendo en una parro-

3. M.F. Fernández chaves y R.M. Pérez García, En los márgenes de la Ciudad de Dios. Moriscos en Sevilla, Valencia, Universitat de València / Universidad de Granada / Universidad de Zaragoza, 2009.

4. En una declaración prestada en 25-IX-1585, Melchor de Berrio, mercader, natural de Granada, y ahora vecino de Sevilla en la collación de Omnium Santorum en la barrera de Álvaro Negro, manifiesta tener 53 años de edad ([A]rchivo [G]eneral de [S]imancas, [C]ámara de [C]astilla, leg. 2209. Pleito contra Ambrosio Pablo de Aguilar).

5. Referencias a deudas contraídas a favor de los Berrio en Baza en 1551 en AGS, [C]ontaduría [M]ayor de [C]uentas-III, leg. 2692, expte. 5.

6. [A]rchivo [H]istórico de [Pr]otocolos de [Gr]anada, G-131, f. 1031r-1034r. Testamento de Daniel Sánchez el Zinety, 13-9-1563. Noticia y análisis de este testamento ya en A. GARCíA PEDRAZA, Actitudes ante la muerte en la Granada del siglo XVI. Los moriscos que quisieron salvarse, vol. II, pp. 876-877. 
quia típicamente de moriscos, como era la de San Gregorio, junto con su esposa Elena y sus hijos Alonso y María, así como con una (esclava) negra, Juana ${ }^{7}$. El hecho de tener dos hijos para este momento retrotrae la fecha del matrimonio a mediados de los años cincuenta, una época para la que Lorenzo de Berrio mantenía ya una estrecha relación económica con su suegro, quien muestra confiar plenamente en él ${ }^{8}$. Melchor de Berrio, por su parte, vivía también en la parroquia granadina de San Gregorio, junto a su hermano'.

Daniel Sánchez el Zinety amasó una considerable fortuna ${ }^{10}$ durante su vida $^{11}$ comerciando con sedas y otros productos, especialmente animales de labranza ${ }^{12}$, y alcanzó una posición dentro de la rica élite mercantil morisca del Albaicín, como lo prueba el hecho de que perteneciera a la cofradía de la Resurrección (de la que también eran cofrades individuos tan significativos y representantivos como Alonso Albotodo, Lázaro Fernández Albeytar, Juan Hernández Mofadal, Miguel López Arroba, Hernán López el Ferí, Andrés Rodríguez el Gamad o Andrés Venegas el Filahi, entre otros), y ejerció incluso labores de representatividad política de su nación. En 1560 llevó junto con el Chapiz unos presentes de boda en nombre de los moriscos granadinos al rey Felipe II, con quien habló personalmente ${ }^{13}$. De su situación social tenemos otros indicios: que perteneciera también a la cofradía Sacramental del Salvador ${ }^{14}$,

7. AGS, CC, leg. 2150, f. 383v. Censo de Granada de 1561.

8. En 1556, Daniel Sánchez del Zinety daba poder a Lorenzo Pérez de Berrio (definido como mercader vecino de Granada) para que en su nombre pudiera cobrar de cualquier persona de la ciudad de Granada o de otra parte por cualquier mercaderías, arrendamientos o censos, pudiendo actuar incluso judicialmente (AHPrGr, G-96, f. 974r-v. Granada, 12-VIII-1556).

9. J. MARTínez RuIZ, «Visita a todas las casas del Albaicín en el año 1569. Conclusiones e índices», Cuadernos de la Alhambra, 22, 1986, p. 126.

10. Aparte de la dote de 2.000 ducados de su hija, y de los gastos derivados de las mandas de su testamento, en este documento declara tener: un molino de moler aceite extramuros de Granada (fuera de la puerta Fajalavza, junto a la casa ollería que fue de Micael Mermo) con tierras y árboles anejos al mismo; un cortijo llamado el Turro con su casa, tierras, huertas y tinados (cobertizos de ganado) en el camino de Alhama; su casa en la collación de San Salvador, mitad suya y mitad de su mujer María Nayara; una tienda en la linería de la Alcaicería que heredó de su padre; tierras en el pago de la Terramonta (en término de Granada), del que lega 30 marjales a su mujer; 300 ducados que ordena se entreguen a su mujer y otros 150 ducados a distintas personas; otra casa en San Salvador que da a Ana Suárez, y una haza de 11 marjales que tenía en el pago de Guid Abrahen (que da a Beatriz Suárez, hija de la anterior) (AHPrGr, G-131, f. 1031r-1034r).

11. Él mismo lo expresa en su testamento: "declaro que la mayor parte de todos los bienes rayzes e muebles e otras cosas que yo tengo y poseo en esta ciudad de Granada como de fuera della, son ganados y adquiridos y multiplicados durante el matrimonio entre mi y la dicha María Nayara mi mujer" (AHPrGr, G-131, f. 1032r).

12. A. García Pedraza, «Los cofrades de la Resurrección, ¿en paz con Dios, en guerra con el fisco?», en prensa. Agradecemos a la autora de este magnífico trabajo habernos facilitado su consulta.

13. Ibídem.

14. A. García Pedraza, Actitudes..., vol. II, p. 876. 
que el escribano Gonzalo Hernández Gabano lo nombrase en 1561 como uno de los curadores y tutores de las personas y bienes de sus hijos ${ }^{15}$, y que sea uno de los pocos moriscos de la ciudad de Granada que en su testamento manda que sobre su sepultura dentro de la iglesia del Salvador "se me ponga una piedra con su letrero a costa de mis bienes"16, presentando según García Pedraza, por las mandas testamentarias de carácter religioso (misas, cortejo fúnebre, sepultura, limosnas...), "un perfil devocional muy en sintonía con el cristiano viejo" ${ }^{\prime 17}$. El medio social en el que se mueve el Zinety es el de la clase artesana y mercantil de la Granada morisca: así lo pone de manifiesto tanto su matrimonio con María Nayara (emparentada a su vez con los Merinís ${ }^{18}$ ), como los individuos que hacen de testigos en 1563 en su testamento: los mercaderes Miguel Sánchez el Zinety y Sebastián Oleylas, Lope el Fahani (tejedor de terciopelo), Melchor el Hipi (tendero), Francisco Bital (sastre) y Lorenzo el Mali (labrador) ${ }^{19}$. Un último apunte sobre la riqueza de los Zinety: la dote de Isabel Sánchez Zinetia (hija de Miguel Sánchez Zinety y María Xoxonia, y que contrae matrimonio con el mercader Lorenzo el Comayhi, hijo a su vez del difunto Juan el Comayhi y de Brianda Afini), ascendió en 1567 a la enorme cifra de $534.845 \mathrm{mrs}$. (a los que habría que sumar otros $37.600 \mathrm{mrs}$. de las arras de su futuro marido $)^{20}$, cuando la media calculada por dote y arras para las mujeres moriscas granadinas de su medio social en estos años rondaba los 170.000 mrs. ${ }^{21}$, y en 1561 las de moriscas tan aristocráticas como doña María Venegas (hija de Alonso Venegas) o doña Gracia Pacheco Abenajara ascendían respectivamente a $359.625 \mathrm{mrs}$. (de los cuales 75.000 corresponden a las arras) y $576.163 \mathrm{mrs}$. (de ellos, 153.886 de las arras), indicando claramente que la riqueza que los Zinety invertían en su reproducción social competía con la de los más granados individuos de la sociedad morisca ${ }^{22}$.

15. Ibídem, vol. II, p. 982.

16. Ibídem, vol. II, p. 876

17. Ibídem, vol. II, p. 716

18. Ya en su día, Amalia García Pedraza señalaba la necesidad, aún pendiente, de indagar las posibles relaciones familiares de éstos con ese Meriní que según algunos testimonios estuvo tras las falsificaciones de la Torre Turpiana (A. GARCíA PedRAZA, Actitudes..., vol. II, p. 876). Sobre este Meriní, D. CABANELAS, El morisco granadino Alonso del Castillo, Granada, Patronato de la Alhambra y Generalife, 1991, pp. 254-255, y M. GARCÍA ARENAL y F. RodRíGueZ-MEdiANO, Un Oriente español. Los moriscos y el Sacromonte en tiempos de Contrarreforma, Madrid, Marcial Pons, 2010, p. 103.

19. AHPrGr, G-131, f. 1031r-1034r. Un mes más tarde Miguel Sánchez el Zinety vuelve a actuar como testigo en el codicilo de Daniel Sánchez el Zinety (AHPrGr: G-131, f. 1080v-1081v. 7-X-1563).

20. AHPrGr, G-158, f. 178r-182v. Dote de Isabel Sánchez Zinetia; Granada, 9-II-1567.

21. M.F. FernÁndez Chaves y R.M. PéRez GARCíA, «Las dotes de las moriscas granadinas y sevillanas. Cambios y adaptaciones de una cultura material», en M. ${ }^{a}$ M. LOBO DE ARAúJO y A. EsTEVES (eds.), Tomar estado: dotes e casamentos (séculos XVI-XIX), Braga, CITCEM, 2010, p. 128.

22. AHPrGr, G-120, f. 351v-358r y 377r-381v. Dotes de doña Gracia Pacheco Abenajara y doña María Venegas. 
Otro indicio del estatus social alcanzado por los Berrio es el de la posesión de esclavos, pues desde las Cortes de Toledo de 1560 los moriscos granadinos lo tenían prohibido ${ }^{23}$ y sólo se les permitía la posesión de los mismos tras obtener una licencia real y demostrar ser buenos cristianos ${ }^{24}$. No obstante, también es cierto que después la prohibición se relajó en el sentido de permitir también tener esclavos a aquellos moriscos o descendientes de moriscos que estuvieran o hubiesen estado casados con cristianas viejas ${ }^{25}$. Ya nos hemos referido a que el censo de 1561 nos informa de que en casa de Lorenzo vivía una negra llamada Juana; de 1567 conocemos la alhorría por la que liberaba a Inés de Berrio, una negra de 30 años $^{26}$. Como indica Aurelia Martín Casares, en esta época sólo "grandes figuras de la élite morisca" $\operatorname{compran}_{\text {esclavos }}{ }^{27}$, y su posesión se hubo de ir convirtiendo cada vez más en un elemento de distinción en el seno de la propia comunidad morisca.

Los datos familiares y sociales de los Berrio, así como los económicos que presentamos a continuación, señalan claramente la plena inserción de éstos en uno de los grupos claves de la élite morisca granadina, el de los ricos mercaderes del Albaicín ${ }^{28}$, que por su modo de vida y manera de testar presentaba un creciente carácter exterior similar al de los cristianos viejos ricos. Sin embargo, un dato en este punto resulta revelador: el 25 de febrero de 1560, Melchor de Berrio salió al auto de fe celebrado por la Inquisición en Granada "por aver dicho palabras en ynjurias de Santo Sacramento y por otras blasfemias", siendo condenado por ello a "vela, soga, mordaça y tres años de galeras" ${ }^{29}$, que no sabemos si finalmente cumpliós ${ }^{30}$ Inauguraba, eso sí, una larga historia de relaciones familiares con la Inquisición.

23. Este problema legal ha sido explicado con detenimiento en J.L. CORTÉs LóPEZ, «Los moriscos y sus esclavos negros», Pliegos de encuentro islamo-cristiano, 17, 1982; y en A. MARTín CASARES, "Moriscos propietarios de personas esclavizadas en Granada a lo largo del siglo XVI», Chronica Nova, 24, 1997, pp. 213-236.

24. A. MARTín CASARES, La esclavitud en la Granada del siglo XVI, Granada, Universidad de Granada y Diputación de Granada, pp. 284-285.

25. M.F. Fernández Chaves y R.M. Pérez García, En los márgenes de la Ciudad de Dios..., p. 43.

26. AHPrGr, G-156, f. 225r-v. Granada, 28-VII-1567.

27. A. Martín Casares, La esclavitud..., p. 285.

28. Sobre la taxonomía de las élites moriscas, véanse especialmente: J. CASTILLO FERNÁNDEZ, «Las estructuras sociales», en M. BARrios Aguilera (ed.), Historia del Reino de Granada, Granada, Universidad de Granada y El Legado Andalusí, 2000, vol. II, pp. 179-230, y B. VINCENT, «Las élites moriscas granadinas», en El río morisco, Valencia, Universidades de Valencia, Granada y Zaragoza, 2006, pp. 187-199, y R.M. Pérez GARCía y M.F. FERnÁndez ChAVEs, Las élites moriscas entre Granada y el Reino de Sevilla. Rebelión, castigo y supervivencias, en prensa.

29. J.M. GARcía FuENTES, La Inquisición en Granada en el siglo XVI, Granada, 1981, p. 17.

30. B. VINCENT, «La Inquisición y los moriscos granadinos», en Minorías y marginados en la España del siglo XVI, Granada, Diputación Provincial de Granada, 1987, pp. 135-136, y B. VINCENT, «Las élites moriscas...», p. 196. 


\section{LAS RELACIONES ECONÓMICAS. LOS NEGOCIOS DE LOS HERMANOS BERRIO ANTES DE LA GUERRA DE GRANADA}

La red comercial tejida por los hermanos Berrio durante las décadas anteriores al estallido de la guerra de Granada era sencillamente impresionante. La comisión aprobada por Felipe II a fines de 1573 para el cobro de todas las deudas impagadas a los Berrio correspondientes a los años anteriores a la guerra generó una voluminosa documentación que nos permite conocerla y aproximarnos a su volumen de negocio. La geografía de sus deudores nos presenta un amplio espacio comercial ${ }^{31}$ que va desde la ciudad de Sevilla ${ }^{32}$, Córdoba y la campiña cordobesa (Montilla ${ }^{33}$, Priego de Córdoba ${ }^{34}$, Benameji ${ }^{35}$, Lucena ${ }^{36}$, Bujalance ${ }^{37} \mathrm{y}$ $\mathrm{Cabra}^{38}$ ) hasta el área jiennense, donde se hallaba su centro fundamental de operaciones e intercambios (desde Andújar ${ }^{39}$, Mengíbar $^{40}$, Jaén $^{41}$ y La Guardia ${ }^{42}$, Baeza y Úbeda ${ }^{43}$, hasta el sur de la provincia con Alcalá la Real ${ }^{44}$, Castillo de Lo-

31. Además de las 49 poblaciones de las que se han conservado y hemos localizado las relaciones de deudores, y que se especifican en las líneas que siguen, tenemos constancia de que la comisión para el cobro de las deudas se hizo también en: el Río de Almanzora (AGS, CMC-III, leg. 3097, expte. 6), la villa granadina de Tarifa (AGS, CMC-III, leg. 2745, expte. 19), Motril (cf. M. ${ }^{a}$ M. BIRRIEL SALCEDO, «Nuevos datos sobre el patrimonio confiscado a los moriscos: la costa de Granada», Chronica Nova, 21, 1993-1994, p. 55), Cabra (AGS, CMC-III, leg. 3033, expte. 27), Martos, Arjona, Arjonilla, Porcuna, Córdoba (AGS, CC, leg. 2180. Copia de la relación que el licenciado Velasco dio en 14-IX-1577), Montejícar (AGS, CC, leg. 2180. Documento de 30-V-1577 "para la cobranza de las deudas que se deben a los moriscos sacados dese reyno"), pero es evidente que se realizó también en otras poblaciones. Por otra parte, la documentación notarial revela que la malla comercial de los Berrio era todavía mucho más densa, y nos ayuda a rellenar las lagunas que presenta la documentación de la CMC-III: aparte de otras localidades que mencionamos en las páginas siguientes, recordemos también a Vélez-Málaga en el Reino de Granada, o a Antequera, Loja o Baena en su límite norte (AHPrGr, G-156, f. 50rv, 59r, 60r-v y 90v respectivamente; Granada, 1567).

32. AGS, CMC-III, leg. 3068, expte. 31.

33. AGS, CMC-III, leg. 2973, expte. 3.

34. AGS, CMC-III, leg. 2973, expte. 3.

35. AGS, CMC-III, leg. 2745, expte. 19.

36. AGS, CMC-III, leg. 3012, expte. 23.

37. AGS, CMC-III, leg. 3223, expte. 15 .

38. AGS, CMC-III, leg. 2951, expte. 1.

39. AGS, CMC-III, leg. 3228, expte. 11.

40. AGS, CMC-III, leg. 2745, expte. 19.

41. AGS, CMC-III, leg. 3228, expte. 11.

42. AGS, CMC-III, leg. 2962, expte. 18.

43. Baeza y Úbeda en AGS, CMC-III, leg. 2745, expte. 19.

44. AGS, CMC-III, leg. 2951, expte. 1. 
cubín $^{45}$, Huelma $^{46}$, Torres $^{47}$, Bedmar $^{48}$ y Quesada ${ }^{49}$, hasta la zona oriental de Cazorla y Villanueva del Arzobispo ${ }^{50}$ ). Las ferias de Úbeda, Baeza y Jaén eran el quicio desde el cual la malla de sus negocios conectaba con el núcleo del sistema mercantil castellano y se extendía hacia el sur de Castilla (negociando con individuos de Alcaraz ${ }^{51}$ o de Almedina ${ }^{52}$ ), el corazón de la Península (Toledo ${ }^{53}$ ), e incluso Medina del Campo ${ }^{54}$. Por supuesto, el centro de su negocio se hallaba en la ciudad de Granada, a la que acudían muchos mercaderes o artesanos de los núcleos de la Andalucía del Guadalquivir para comprarles sus productos, escriturando sus operaciones ante diversos escribanos públicos de la capital. Desde ella abastecían el conjunto del Reino de Granada, desde la zona almeriense (el marquesado de Los Vélez ${ }^{55}$, el Río de Almanzora ${ }^{56}$, y Andarax hasta Adra ${ }^{57}$ ), a todo el territorio de la actual provincia de Granada (las Alpujarras granadinas ${ }^{58}$, los grandes núcleos de Guadix y Baza ${ }^{59}$ con sus alfoces, el estratégico enclave de la comarca de Huéscar ${ }^{60}$, y numerosas poblaciones del norte y oeste de la provincia $\left.^{61}\right)$, hasta llegar al extremo occidental del Reino, con Marbella y Ronda ${ }^{62}$, ciudad y su feria en la que hacían importantes negocios.

Las deudas que los Berrios reclamaban a los 215 deudores que censamos en las 49 poblaciones que hemos podido documentar ascendían a 5.516 .312 mrs. (unos 14.710 ducados), resto de deudas anteriores y de obligaciones de pago que vencían en su mayoría entre los años 1566-1569 y que originariamente habían supuesto 10.035 .090 mrs. (algo más de 26.760 ducados). Sin embargo, no podemos olvidar que estas cantidades fueron muy superiores, pues-

\footnotetext{
45. AGS, CMC-III, leg. 2951, expte. 1.

46. AGS, CMC-III, leg. 2470, expte. 8.

47. AGS, CMC-III, leg. 2745, expte. 19.

48. AGS, CMC-III, leg. 3012, expte. 23.

49. AGS, CMC-III, leg. 2745, expte. 19.

50. AGS, CMC-III, leg. 2774, expte. 1.

51. AGS, CMC-III, leg. 2778, expte. 3.

52. AGS, CMC-III, leg. 3033, expte. 27.

53. AGS, CMC-III, leg. 2735, expte. 21.

54. AGS, CMC-III, leg. 2757, expte. 8.

55. Vélez Rubio y la villa de Las Cuevas. Cf. AGS, CMC-III, leg. 2745, expte. 19.

56. AGS, CMC-III, leg. 3097, expte. 6.

57. AGS, CMC-III, leg. 2642, expte. 23.

58. Ugíjar y Pitres de Ferreira. Cf. AGS, CMC-III, leg. 2642, expte. 23.

59. Junto con Zújar, Cúllar y Caniles de Baza. Cf. AGS, CMC-III, leg. 2692, expte. 5.

60. Además de Huéscar, Galera, Orce, La Puebla de Borteruela (o de Don Fadrique) y Castril, y hacia el sur Tarifa. Cf. AGS, CMC-III, leg. 3097, expte. 6.

61. Como Loja, Iznalloz, Huétor Tájar, Escúzar. Cf. AGS, CMC-III, leg. 2883, expte. 10.

62. AGS, CMC-III, leg. 2951, expte. 1.
} 
to que ni siquiera conocemos la lista de deudores de la ciudad de Granada, o de otros núcleos importantes como Málaga, Almería o Motril donde sabemos que los Berrio realizaban diversos tratos. El cálculo que hizo el contador Martín Pérez de Arriola, tras reconstruir entre octubre y noviembre de 1573 las listas de deudores de los Berrios, elevó la cifra que montaban las deudas que los particulares debían a éstos a 8.969.323 mrs. y 147 arrobas de aceite ${ }^{63}$, lo que supone que la información proporcionada por las 49 poblaciones citadas corresponde sólo al 61,5\% del total de la deuda. Haciendo una extrapolación, podríamos afirmar con bastante seguridad que el volumen originario de deuda del que era resto esa cantidad habría ascendido en su origen a más de 16.316.000 mrs., es decir, más de 43.500 ducados, una cantidad verdaderamente astronómica, y que, insistimos de nuevo, no representa a su vez sino una parte de las cantidades movidas por la actividad comercial de Lorenzo y Melchor de Berrio en los años inmediatamente anteriores a la guerra.

El negocio de los Berrio abastecía tanto al pequeño comercio como al mediano e incluso al grande. La distribución de los 215 deudores conocidos en función del tamaño de su deuda con los hermanos Berrio nos informa que una multitud de individuos les adeudaban cantidades muy pequeñas (en 102 casos, que suponen el 47,45\% del total de deudores, se les debía menos de 10.000 mrs.) en relación con un comercio al por menor o incluso con la venta a particulares para su consumo; junto a ellos, coexiste otro $45,1 \%$ de deudores ( $97 \mathrm{su}-$ jetos) que les deben cantidades medianas que oscilan entre 10.000 y 90.000 mrs.; por encima de los 100.000 mrs., una cantidad ya respetable (equivale a algo más de 266 ducados), se sitúan únicamente 16 individuos (el 7,45\%), los cuales concentran casi el $44 \%$ (2.425.392 mrs.) del total de la deuda reclamada por los Berrio en esas 49 poblaciones. En la gráfica 1 están representados los datos correspondientes a las 49 poblaciones conocidas.

Por otra parte, el repaso de la nómina de mayores deudores nos informa de los grandes nodos comerciales con los que los Berrio estaban conectados: desde Granada hacia el siguiente centro principal donde negociaban sus mercancías (el triángulo formado por las ferias de Jaén, Úbeda y Baeza), y luego Huéscar (con su papel capital en el negocio de la lana granadina), Ronda (gran demandante de productos de los Berrio), Sevilla y Medina del Campo, importantes puntos de redistribución; otras poblaciones de esta lista (Quesada, Bujalance, Montilla o Alcalá la Real) representan fundamentalmente lugares donde residen grandes compradores de mercancías de los Berrio.

La distribución de la deuda por provincias corrobora esta geografía económica de los Berrio.

63. AGS, CC, leg. 2178. Javier Castillo interpreta este dato, pensamos que inadecuadamente, como el valor de la fortuna que se les habría calculado a los Berrio (J. CASTILLO FERNÁNDEZ, op. cit., vol. II, p. 203). 
Los mayores deudores de los Berrio (más de $100.000 \mathrm{mrs}$.) a fines de 1573 según las relaciones del contador Martín Pérez de Arriola. En mrs.

\begin{tabular}{|c|c|c|c|}
\hline POBLACIÓN & DEUDOR & $\begin{array}{l}\text { DEUDA } \\
\text { RECLAMADA }\end{array}$ & $\begin{array}{l}\text { DEUDA } \\
\text { ORIGINARIA }\end{array}$ \\
\hline Baeza & Cristóbal Gutiérrez & 268.088 & 476.058 \\
\hline Úbeda & Alonso Moreno & 190.308 & 256.186 \\
\hline Baza & Pedro Moreno & 175.737 & 175.737 \\
\hline Huelma & $\begin{array}{l}\text { Diego Hernández } \\
\text { Omayra }\end{array}$ & 170.393 & 204.393 \\
\hline Sevilla & $\begin{array}{l}\text { Andrés López y } \\
\text { su mujer Mari Díaz }\end{array}$ & 167.300 & 167.300 \\
\hline $\begin{array}{l}\text { Medina del } \\
\text { Campo }\end{array}$ & $\begin{array}{l}\text { Diego Hernández } \\
\text { de Baeza }\end{array}$ & 166.979 & 166.979 \\
\hline Quesada & Luis de Olivares & 161.899 & 202.892 \\
\hline Alcalá la Real & Alonso de Oñate & 158.855 & 158.855 \\
\hline Baeza & Martín Pérez, mercader & 150.540 & 218.540 \\
\hline Bujalance & Luis Nieto de Narváez & 141.616 & 219.147 \\
\hline Ronda & Melchor Hernández ${ }^{64}$ & 124.186 & 145.748 \\
\hline Huéscar & $\begin{array}{l}\text { Alonso Hernández } \\
\text { Aburrabe, morisco }\end{array}$ & 119.192 & 207.650 \\
\hline Úbeda & Bartolomé de Santisteban & 117.344 & 267.044 \\
\hline Jaén & $\begin{array}{l}\text { Gaspar Carrillo (difunto) } \\
\text { y su mujer }\end{array}$ & 108.705 & 130.465 \\
\hline Montilla & Francisco Martínez & 102.900 & 123.300 \\
\hline Quesada & Diego de Çambrana & 101.350 & 300.772 \\
\hline
\end{tabular}

Fuente: AGS, CMC-III, legajos citados.

Si consideramos aquellos 13 núcleos de población cuyos deudores acumulaban más de 150.000 mrs. (400 ducados) de deuda en 1573 según las relaciones del contador Pérez de Arriola, hallamos que concentran 4.540 .357 mrs., es decir, el $82,3 \%$ de la deuda conocida para las 49 poblaciones que estudiamos. Ello significa que si bien es cierto que el territorio en que operan los Berrio es extensísimo, también lo es que principalmente lo hacen con núcleos de cierta importancia, no penetrando habitualmente en las zonas rurales y poblaciones de menor entidad (salvo en el Reino de Granada). Lo hemos representado en la gráfica 3.

64. Esta deuda era reclamada a Melchor Hernández, su mujer, su padre Diego Hernández, Juan Rubio y Gonzalo Caballero. 
Gráfica 1. Distribución de los deudores de los hermanos Berrio según tamaño de la deuda (1573).

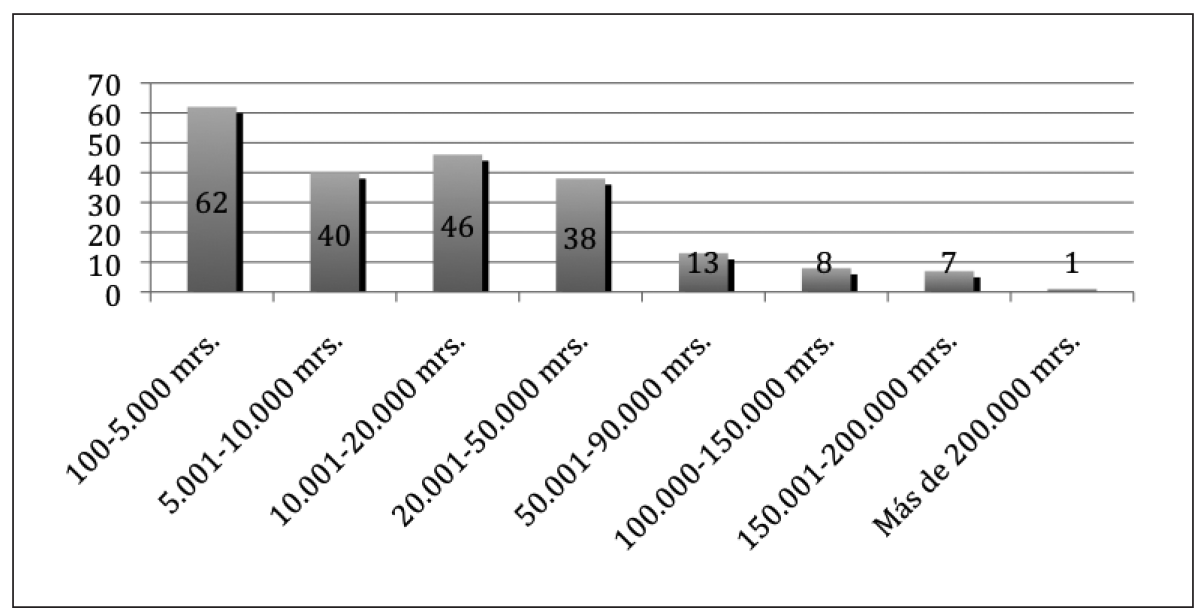

Gráfica 2. Distribución por provincias de las deudas a los Berrio (49 poblaciones conocidas).

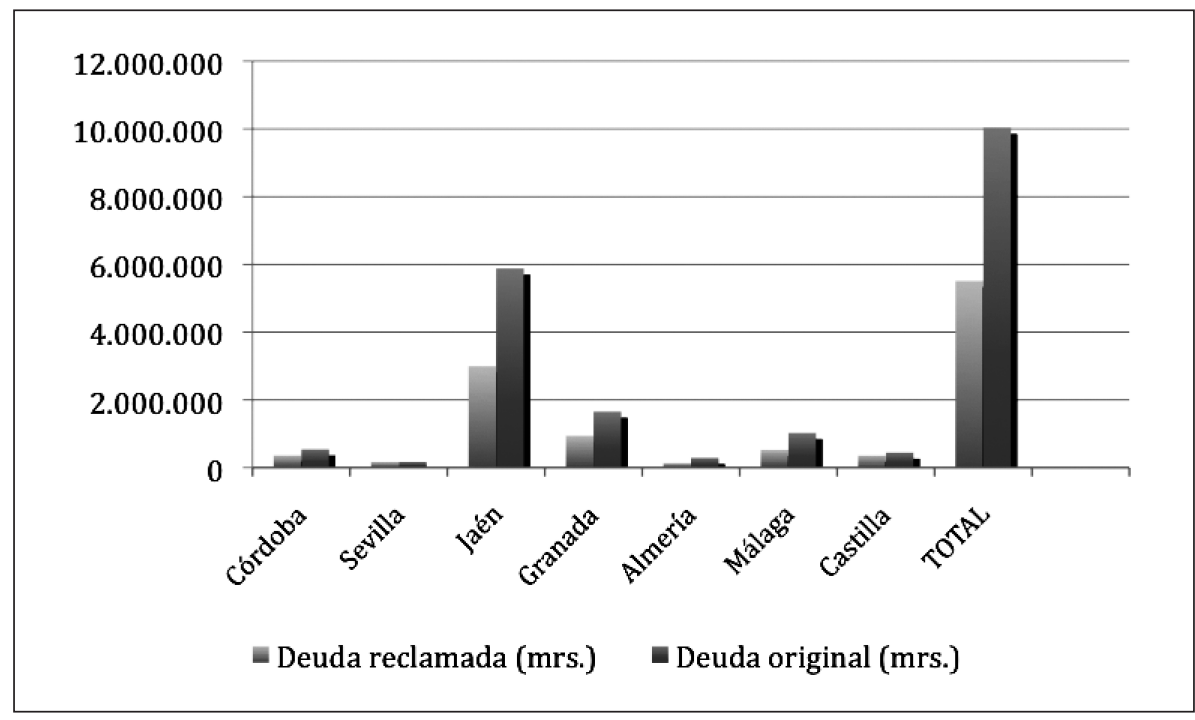

Fuente: AGS, CMC-III, legajos citados. 
Gráfica 3. Localidades con deudores de los Berrio a fines de 1573. Deudas mayores a 150.000 mrs.

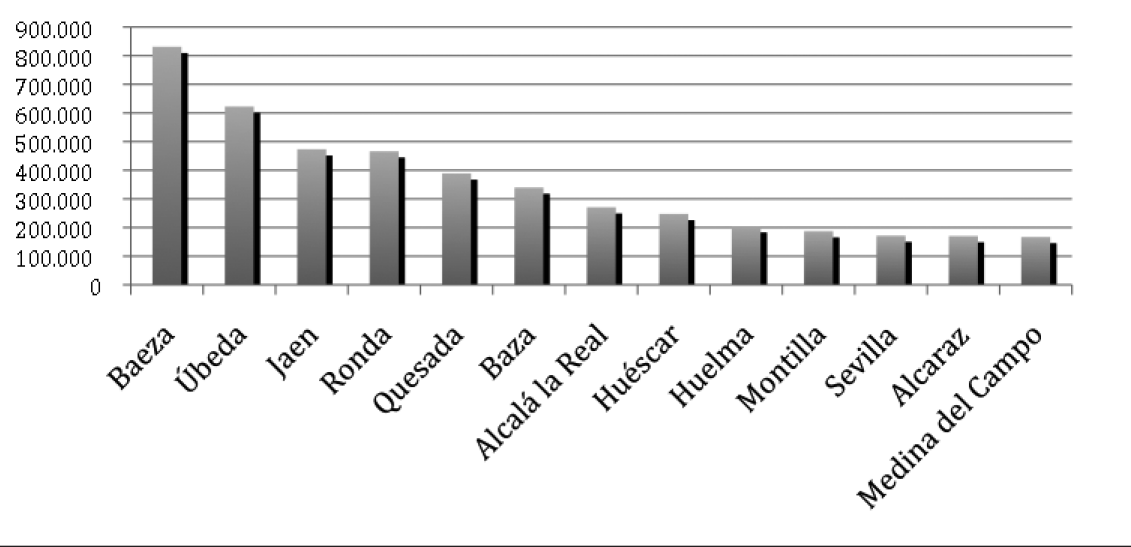

La tipología de personas que hacían negocios con los Berrio está en lógica relación con la gama de productos que éstos comercializaban. De los 84 individuos de quienes la documentación de la Contaduría Mayor de Cuentas nos proporciona su oficio, 23 son artesanos del sector textil ${ }^{65}, 8$ son especieros (dos de Jaén, uno de Úbeda, tres de Ronda uno de Marbella y otro en Las Cuevas en Los Vélez) y 8 boticarios ${ }^{66}$ (tres en Ronda, dos en Jaén, y otros en Baeza, Úbeda, y Baza), 17 mercaderes ${ }^{67}$, otros 25 serían trabajadores de distinto tipo $^{68}$, y tres encuadrables dentro de las élites locales ${ }^{69}$, aunque es claro que la mayoría de aquellos de quienes la documentación no especifica su profesión son mercaderes o pertenecen también a esos sectores artesanales demandantes de los productos en que se hallaban especializados los Berrio. Las lis-

65. Del textil y los complementos: tres calceteros, un bordador, dos cardadores, un cintero, un cordonero, un guantero, dos lenceros, un mercero, dos sastres, tres sederos, un tejedor de paños, cuatro tintoreros y un guarnicionero.

66. Existía una estrecha relación y similitud entre boticarios y especieros. Una prueba la tenemos en el hecho de que las Ordenanzas de Sevilla de 1411, 1527 y 1632 se dirijan conjuntamente a "especieros y boticarios", por la relación de los productos comercializados por los mismos, aunque estas ordenanzas estarían por ello totalmente desfasadas en el aspecto farmacéutico (M. FernÁNDEZ-CARrión y J.L. VALVerde, Farmacia y sociedad en Sevilla en el siglo XVI, Sevilla, Ayuntamiento, 1985, pp. 13-14).

67. Y de ellos, uno de paños, otros dos de sedas y uno además especiero.

68. Dos arrieros, cinco carpinteros, tres carderos, un cerero, dos confiteros, cuatro espaderos, un herravejero, dos labradores de hoja, dos mayordomos, un molinero y dos pintores.

69. Un capitán, un regidor y un escribano de su majestad. 
tas de deudores de 1573 rara vez aclaran cuáles son esos productos, pero aun así se mencionan una veintena de ellos: especias en general ${ }^{70}$, canela, pimienta ${ }^{71}$, azafrán ${ }^{72}$, clavo ${ }^{73}$, incienso ${ }^{74}, \operatorname{cera}^{75}$, pasa $^{76}$, brasil $^{77}$, azúcar ${ }^{78}$, alca$\operatorname{cer}^{79}$, coral $^{80}$, papel de marquilla ${ }^{81}$, solimán ${ }^{82}$, hilo de hierro ${ }^{83}$, hierro ${ }^{84}$, bece-

70. Rodrigo de Ayala, escribano de su majestad y vecino de Baeza, les debía 187 mrs. por ciertas especias que les compró en la feria de San Andrés de 1565 (AGS, CMC-III, leg. 2745, expte. 19).

71. Pedro de la Cosa, mercader, vecino de Villanueva del Arzobispo y estante en Úbeda, compraba en octubre de 1568 a los Berrio una libra de canela, tres libras de azafrán y una arroba de pimienta (AGS, CMC-III, leg. 2774, expte. 1).

72. Andrés Gutiérrez, cordonero, vecino de Jaén, les compró cuatro onzas de azafrán por 1.972 mrs. en la feria de agosto de 1568 (AGS, CMC-III, leg. 3228, expte. 11).

73. Don Francisco de Ahumada, vecino de Ronda, quedó a deber $136 \mathrm{mrs}$. por cuatro onzas de clavo "que se le dieron en feria de Ronda de 1567" (AGS, CMC-III, leg. 2951, expte. 1).

74. Juan López Marruecos, vecino de Jaén, debía pagar a los Berrio 238 mrs. por una libra de incienso que se le dio en feria del viernes santo de 1568 (AGS, CMC-III, leg. 3228, expte. 11).

75. El cerero Hernán Jiménez de Benalcázar, vecino de Jaén, compró a los Berrio un quintal de cera por 9.000 mrs. en la feria del viernes santo de 1567 (AGS, CMC-III, leg. 3228, expte. 11).

76. Los hermanos Francisco y Juan Fernández, cardadores vecinos de Jaén, adquirieron dos cargas de pasa (AGS, CMC-III, leg. 3228, expte. 11).

77. El tintorero Juan de Linares, vecino de Baeza, compró 21 libras de brasil por 10.574 mrs., de los que hizo obligación ante un escribano de su ciudad para pagarlos el viernes santo de 1569 (AGS, CMC-III, leg. 2745, expte. 19).

78. El confitero Juan López, vecino de Jaén, compró 23 libras de azúcar por 25.885 mrs. en la feria de agosto de 1567 (AGS, CMC-III, leg. 3228, expte. 11).

79. El morisco Luis Enríquez Alcalde, vecino de Orce, acudía a Úbeda (tanto a sus ferias, como la de 1567, y en otros momentos, como en octubre de 1568) a comprar a los Berrios, de los que adquirió 200 libras de "alcoçer" en esta última fecha (AGS, CMC-III, leg. 3097, expte. 6).

80. El mercader Jerónimo Hernández, vecino de Andújar, les compró coral en la feria de Úbeda de agosto de 1556 (AGS, CMC-III, leg. 3228, expte. 11).

81. Alonso y Pero Ruiz, pintores vecinos de Jaén, compraron cinco resmas de papel de marquilla por 3.750 mrs. que les entregó Cristóbal Gutiérrez, vecino de Baeza, en nombre de los Berrio. Pero Gómez, también pintor y vecino de Jaén, les compró una resma de papel de marquilla por 816 mrs., que debía pagarles el viernes santo de 1567 (AGS, CMC-III, leg. 3228, expte. 11).

82. Cristóbal Gutiérrez, vecino de Baeza que solía negociar con los Berrio en las ferias de Baeza y Jaén, recibió de éstos 100 libras de solimán en 13-VI-1567 que les debía abonar en el siguiente día de San Miguel (AGS, CMC-III, leg. 2745, expte. 19). Leonor de Cadena, vecina de Jaén, y que también trataba con ellos en ferias, les debía pagar en 1568 la cantidad de 1.870 mrs. por dos libras de solimán "que se le enviaron por su carta con Diego Ruiz" (AGS, CMCIII, leg. 3228, expte. 11).

83. El cardero Juan de Alcázar, vecino de Jaén, les compró "cierto hilo de hierro" en la feria de agosto de 1567, que les debería pagar un año después por la misma fecha (AGS, CMC-III, leg. 3228, expte. 11).

84. Alonso Moreno, vecino de Úbeda, les debía dinero por la compra de hierro (AGS, CMC-III, leg. 2745, expte. 19). 
$\operatorname{rros}^{85}$, y algunos tejidos tales como tafetán ${ }^{86}$, telilla de oro y seda ${ }^{87}$, sedas ${ }^{88}$, anascote $^{89}$ y mitán ${ }^{90}$.

Parece claro que el comercio de especias ocupaba el centro de su actividad, pero el abanico completo de productos intercambiados era verdaderamente muy amplio, normalmente con el perfil característico de productos generadores de altos márgenes de beneficios y / o relacionados con el comercio internacional. La documentación notarial granadina confirma esta imagen y nos informa además de que la estructura tipológica de su negocio se mantuvo bastante homogénea durante toda la etapa anterior a la guerra. Así lo expresa el estudio de una muestra de 33 documentos correspondientes a compraventas y reconocimientos de deuda por parte de sus compradores, diez correspondientes al año 1555 y 23 del año $1567^{91}$. El análisis de los productos que aparecen en estas 33 escrituras nos devuelve de nuevo la imagen del predominio de las especias, que suponen el 50\% de los intercambios (32 sobre 64), pero también la de la amplitud del negocio de los hermanos Berrio, en el que el papel y los textiles (con un 12,5\% de los intercambios cada uno de ellos) representan otra fracción sustancial del mismo. En la gráfica 4 se han expresado estos resultados con detalle.

El análisis del valor de los productos contenidos en 21 de las escrituras de 1567 (aquellas que nos permiten calcularlo ${ }^{92}$ ) corrobora el resultado anterior, pero con interesantes matices. Las especias (azafrán, pimienta y clavo) suponen

85. El especiero Martín Navarro, vecino de Úbeda, les compró varias docenas de becerros (AGS, CMC-III, leg. 2745, expte. 19).

86. Luis de Olivares, vecino de Quesada, que trataba con los Berrio en las ferias de Jaén o Úbeda, les compró 24 varas de tafetán por 4.692 mrs. (AGS, CMC-III, leg. 2745, expte. 19).

87. El capitán Leonardo de Valdivia, vecino de Baeza, les compró un corte de telilla de oro y seda por 33 reales (AGS, CMC-III, leg. 2745, expte. 19). Otro indicio del interés de los Berrio por las sedas: Luis Sánchez de Córdoba, vecino de Jaén, les debía pagar en sedas una parte de su importante deuda (AGS: CMC-III, leg. 3228, expte. 11).

88. Diego Hernández de Baeza, mercader de sedas vecino de Medina del Campo, debía a los Berrio en 1573166.979 mrs. "de resto de dos cajas de sedas que se le vendieron" (AGS, CMC-III, leg. 2757, expte. 8).

89. De Francisco de las Casas, vecino de Castillo de Locubín, que tenía tratos bastante habituales con los Berrio, sabemos que les compró una pieza de anascote "y otras cosas" por $6.797 \mathrm{mrs}$. (AGS, CMC-III, leg. 2951, expte. 1).

90. El lencero y trapero Diego Rodríguez, vecino de Baeza, les debía 3.553 mrs. por cuatro piezas de mitanes (AGS, CMC-III, leg. 2745, expte. 19).

91. Para el año 1555, AHPrGr, G-91, f. 192r, 194r, 196r, 197r, 199r, 201r, 202r, 203v, 204v, 207v; para 1567, AHPrGr, G-156, f. 1r-v, 6v, 7r, 7v, 9r, 10r, 11r, 12r, 12v, 13r, 14r, 14v, 155v-156r, 210r-v, 214r-v, 215r-v, 216r-v, 226r-v, 221r-222r, 282v, 284r, 298r-299r, 336v-337r (todas las foliaciones según la numeración moderna).

92. AHPrGr, G-156, f. 1r-v, 6v, 7r, 7v, 9r, 10r, 11r, 12r, 12v, 13r, 14r, 14v, 155v-156r, 210r-v, 215r-v, 216rv, 226r-v, 221r-222r, 282v, 284r, 298r-299r, y que suman un valor de algo más de $313.000 \mathrm{mrs}$. No consideramos los documentos de 1555 por el efecto deformante que en los precios podría suponer valorar conjuntamente datos de dos fechas tan distantes. 
Gráfica 4. Productos comercializados por los Berrio en 33 escrituras notariales de 1555 y 1567. Número de veces que aparece cada producto.

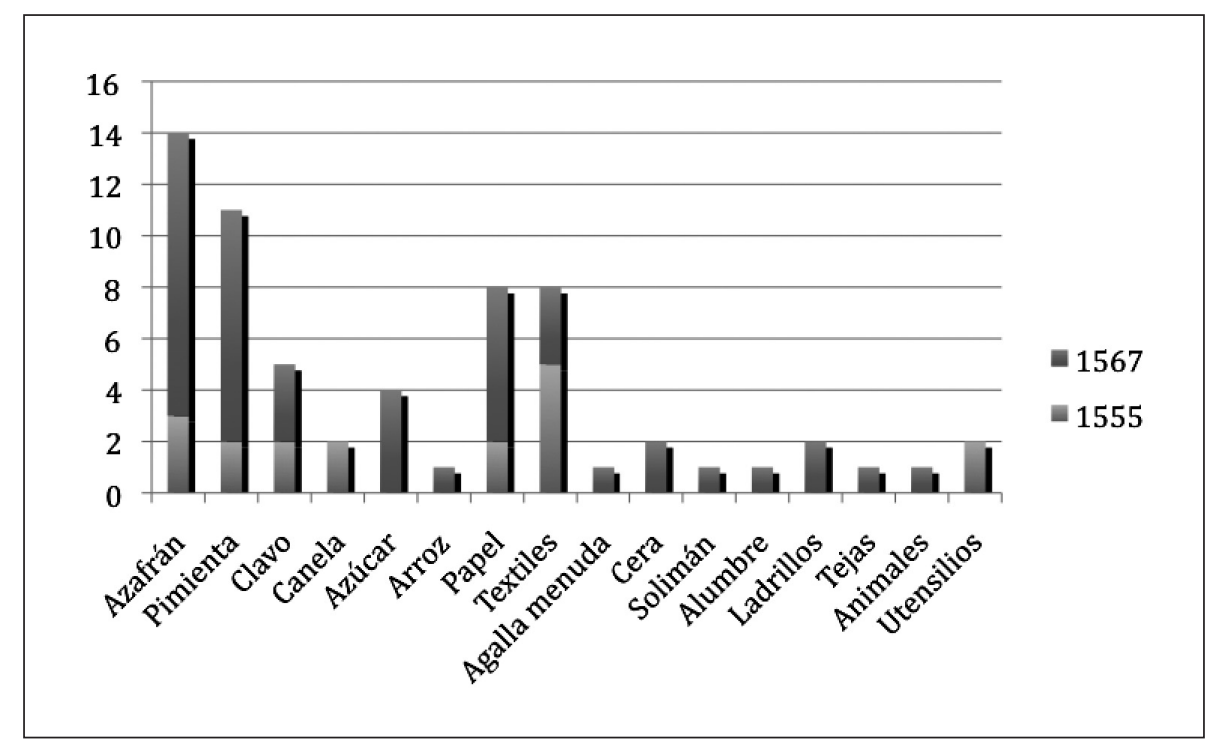

Gráfica 5. Valor representado por los distintos productos comercializados por los Berrio en el conjunto de su negocio en 1567 (sobre 23 escrituras notariales; en \%).

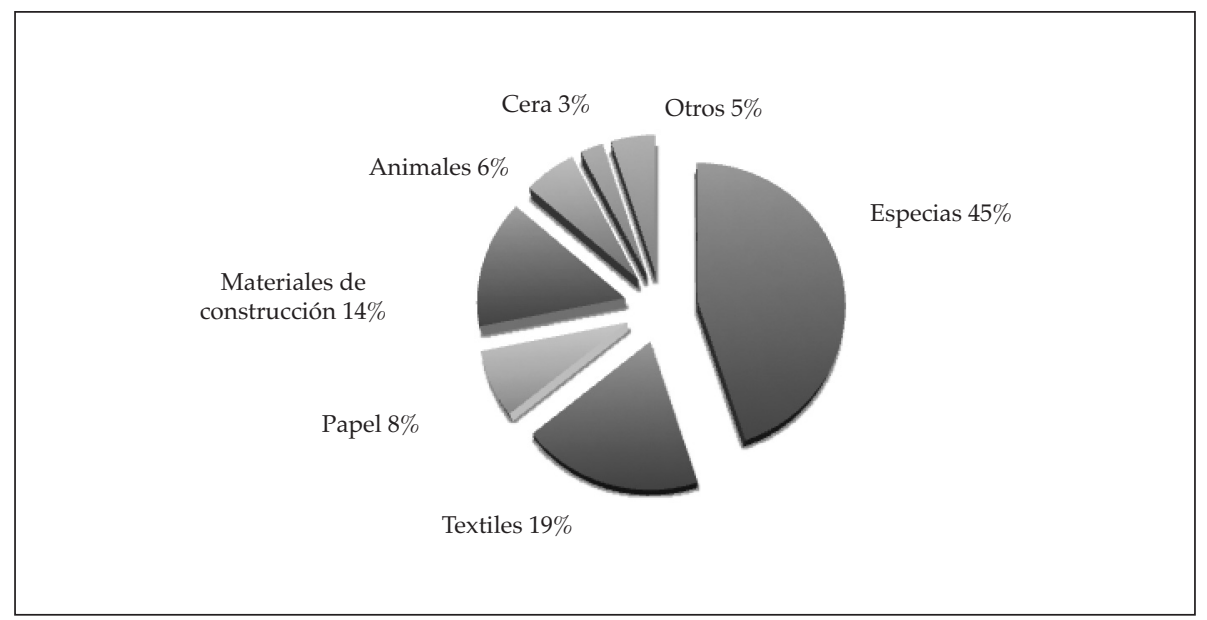


el $45 \%$ del valor de negocio, los textiles el 19,2\%, el papel el 7,6\%, los materiales de construcción (ladrillo y teja a entregar en el tejar de Salobreña, junto al ingenio de Flores y la muralla ${ }^{93}$ ) el 14,6\%. En la gráfica 5, que redondea los valores, puede verse el desglose de las partidas ${ }^{94}$.

La documentación notarial granadina nos revela que la ciudad de Granada funcionaba como centro del negocio y de la red mercantil de Lorenzo y Melchor de Berrio. Ello se comprueba especialmente en lo que era el núcleo de su comercio, las especias. A Granada acudían mercaderes interesados en ellas procedentes de todas las partes del Reino de Granada a adquirirlas a través de los Berrio y a saldar sus deudas con ellos: de la taha de Ugíjar ${ }^{95}$, de Andarax ${ }^{96}$, de la costa de Almuñécar ${ }^{97}$, de La Peza ${ }^{98}$, de Almería ${ }^{99}$, de la comarca de Huéscar $^{100}$, etc. También eran muchos los mercaderes y arrieros de la zona de Jaén ${ }^{101}$ o del área andaluza fronteriza con el Reino de Granada (Rute ${ }^{102}$, Archidona ${ }^{103}$, etc.) que se acercaban a Granada a comprar género a los Berrio y escriturar sus deudas ante los notarios de la ciudad. Las cantidades representadas solo en

93. AHPrGr, G-156, f. 210r-v y 298r-299r.

94. El capítulo de "Otros" incluye: azúcar, solimán, arroz y agalla menuda.

95. Benito de la Mata el Darravec, de la taha de Ugíjar, se obligaba en Granada a pagarles 8.777 mrs. que les debía por cuatro libras de azafrán, dos arrobas de azúcar y tres libras de clavo (AHPrGr, G-156, f. 7r. Granada, 12-V-1567).

96. Rafael el Cayar?, tendero, vecino de Andarax de las Alpujarras, reconoce tener que pagar a Lorenzo de Berrio 7.881 mrs. por ocho libras de azafrán (AHPrGr, G-91, f. 207v. Granada, 20-II-1555).

97. Lorenzo de Mansilla Alohaymar, vecino de Utibay en la jurisdicción de Almuñécar, reconocía en Granada deber a los Berrio 53 reales y medio por tres libras de pimienta, una libra de azafrán y un cuarto de arroba de arroz (AHPrGr, G-156, f. 284r. Granada, 31-VII-1567).

98. Francisco el Ghayti, vecino de la Peza y estante en Granada, reconocía deber en esta ciudad a Lorenzo de Berrio sesenta reales por dos libras de azafrán (AHPrGr, G-91, f. 199r. Granada, 1-II-1555).

99. Luis de Jaén el Tanjí, vecino de Almería y estante en Granada, reconocía deberles 64.224 mrs. por un quintal de pimienta, veinte libras de azafrán y otros productos (AHPrGr, G-156, f. 10r. Granada, 28-V-1567).

100. Juan Leonís, mercader de especiería y vecino del lugar de La Puebla de Borteruela (o de Don Fadrique) en la jurisdicción de Huéscar, reconoce en Granada deberles 12.000 mrs. por razón de seis libras de azafrán y 30 libras de pimienta (AHPrGr, G-156, f. 13r. Granada, 14-VI-1567).

101. Por ejemplo, Pedro Gutiérrez de las Doblas, vecino de Jaén, que durante su estancia en Granada reconoce deber a los Berrio 368 reales por el azúcar que les compró (AHPrGr: G-156, f. 6v); o Diego Fernández de Umaña, vecino de Huelma, 25.883 mrs. por dos arrobas de pimienta, ocho libras de azafrán y tres resmas de papel (AHPrGr, G-156, f. 9r).

102. Juan de Palma, labrador y mercader de Rute, reconocía en 1567 en Granada deber a los hermanos Berrio 49.820 mrs. por un quintal de pimienta, diez libras de azafrán, dos libras de clavo, seis libras de solimán y un balón de papel de 22 resmas (AHPrGr, G-156, f. 14v).

103. Diego Fernández Machón y el arriero Alonso Fernández, vecinos de Archidona, se obligaban en abril de 1567 a pagar cuatro ducados a los Berrio por libra y media de azafrán que éstos les habían suministrado (AHPrGr, G-156, f. 1r-v). También Adán López, vecino de Archidona, reconocía deberles 7.609 mrs. por una arroba de pimienta, dos libras de azafrán y una arroba de azúcar (AHPrGr, G-156, f. 221r-222r. Granada, 2-VIII-1567). 
los ejemplos que presentamos aquí son ya harto expresivas de los importantes cargamentos de especias comercializados por los Berrio.

Ya nos hemos referido a cómo los productos textiles, uno de los grandes negocios del siglo, ocuparon un lugar destacado entre las actividades de los Berrio. Como parece que era habitual en su comportamiento mercantil, los Berrio vendían tanto a comerciantes y artesanos en cantidades de cierta relevancia, como a particulares al por menor. Entre los primeros podemos destacar al mercader Fernando de León, vecino de Granada, que debía dinero a Lorenzo de Berrio por dos docenas de mangas coloradas grandes (a $1.000 \mathrm{mrs}$. la docena) y seis docenas de calcetas de lana (a cinco reales la docena) ${ }^{104}$; a los zapateros Hernán Ruiz y Juan Ruiz, también vecinos de Granada, que en 1567 les compraron 31 vaquetas de Flandes curtidas y teñidas ${ }^{105}$; o a Diego de Almansa Gallini, también vecino de Granada, que les compró siete varas de anascote por 45 reales y medio ${ }^{106}$. En el segundo grupo podríamos recordar a Martín Godínez, regidor de Vera que aprovecha su estancia en Granada para comprarles cinco vasquiñas de paño negro florete ${ }^{107}$; al hortelano Martín Melique y al albardero Miguel de Almansa, vecinos de Granada, que debían en 1555 a Lorenzo de Berrio 60 reales por dos fundas ${ }^{108}$; al trabajador granadino Lope Mayiel, que compró a los hermanos Berrio una vara y media de paño picadilo por 18 reales $^{109}$; o aquellos hermanos moriscos, hortelano de Granada y labrador de las Albuñuelas respectivamente, que les compraron una vara de paño pardo ${ }^{110}$.

Los hermanos Berrio también abastecían de papel a la industria editorial de Granada. Conocemos una operación por la que el impresor Renet Rabut, vecino de Granada, les compraba en 1567 diez resmas de papel de veta verde por 3.400 mrs. ${ }^{111}$. También el librero granadino Juan de Noguerol les compró ese mismo año veinte resmas de papel de veta verde a nueve reales y media la resma ${ }^{112}$. Otras veces son comerciantes los que compran pequeñas cantidades de papel a los Berrio: así el mercader de especiería granadino Juan Pérez, que además de comprarles una arroba de pimienta, 25 libras de clavo y canela y otras 10 libras de azafrán, les compró dos resmas de papel por $602 \mathrm{mrs} .^{113}$, el al-

104. AHPrGr, G-91, f. 201r. Granada, 12-II-1555.

105. AHPrGr, G-156, f. 7v. Granada, 14-V-1567. A razón de tres ducados y medio cada vaqueta, la cantidad a pagar ascendía a 108 ducados y medio.

106. AHPrGr, G-156, f. 14r. Granada, 19-VI-1567.

107. AHPrGr, G-91, f. 192r. Granada, 21-I-1555.

108. AHPrGr, G-91, f. 203v.

109. AHPrGr, G-91, f. 204v. Granada, 18-II-1555.

110. AHPrGr, G-91, f. 202r. Granada, 14-II-1555.

111. AHPrGr, G-156, f. 226r-v. Granada, 28-VII-1567.

112. AHPrGr, G-156, f. 12v. Granada, 12-VI-1567.

113. AHPrGr, G-91, 194r. Granada, 24-I-1555. 
meriense Luis de Jaén el Tanjí, que junto a pimienta y azafrán, les compró diez resmas de papel ${ }^{114}$, o el tendero y tejedor de terciopelo Pedro de Bustos, que además de comprarles las mismas cuatro especias, también se obligó a pagar a Lorenzo de Berrio diez reales por cada una de las seis resmas de papel que éste le proporcionó ${ }^{115}$. Idéntico es el caso de Francisco López Camafeo, vecino de Archidona que va a Granada a comprar a los Berrio pimienta, azafrán, azúcar y una resma de papel de estraza en 135 mrs. ${ }^{116}$. Como en el caso de los géneros anteriores, se trataba de un producto caro $^{117}$, y del que la mayor parte del utilizado por la imprenta española de la época se importaba de Francia e Italia. En la mayoría de los casos conocidos, el papel suministrado para la imprenta en la Sevilla incunable y de comienzos del siglo XVI era proporcionado por mercaderes genoveses (Pinelos, Dorias, Spínolas, etc.) ${ }^{118}$. La importación de papel durante el siglo XVI fue continuamente dificultada por las guerras con Francia, lo que hace lógico pensar que favorecía la vía italiana: ya en 1523 escaseaba y era caro por esta causa ${ }^{119}$, y de nuevo a fines de la década de 1550, la nueva guerra con Francia hizo que el papel volviera a escasear en Sevilla ${ }^{120}$ y sus precios subieran. Si en el norte de Castilla existió una cierta actividad de molinos de papel para abastecer a las imprentas de la región, especialmente de Burgos ${ }^{121}$, y en la coyuntura crítica de los años cincuenta se detecta la construcción de otros nuevos con el fin de sustituir las importaciones desaparecidas ${ }^{122}$, no parece que en Andalucía haya sucedido lo mismo, abocando a la región a una radical dependencia exterior en cuanto al papel, que durante todo el siglo fue reexportado en cantidades importantes desde el puerto de Sevilla hacia el área atlántica ${ }^{123}$. En el caso del Reino de Granada parece clara la dependencia del papel italiano, suministrado nuevamente por las redes comerciales genovesas.

114. AHPrGr, G-156, f. 10r. Granada, 28-V-1567.

115. AHPrGr, G-91, 196r. Granada, 28-I-1555.

116. AHPrGr, G-156, f. 216r-v. Granada, 22-VII-1567.

117. C. GRIFrin, Los Cromberger. La historia de una imprenta del siglo XVI en Sevilla y Méjico, Madrid, Ediciones de Cultura Hispánica, 1991, p. 26.

118. Por ejemplo, véase J. HaZAÑas Y la RÚA, La imprenta en Sevilla. Noticias inéditas de sus impresores desde la introducción del arte tipográfico en esta ciudad hasta el siglo XIX, Sevilla, Diputación Provincial de Sevilla, 1945, vol. I, pp. 29, 60, 76-78, etc.

119. V. Beltrán de Heredia, Cartulario de la Universidad de Salamanca, Universidad de Salamanca, Salamanca, 1970, vol. II, pp. 422-423.

120. K. WAGNer, Martín de Montesdoca y su prensa. Contribución al estudio de la imprenta y de la bibliografía sevillanas del siglo XVI, Sevilla, Universidad de Sevilla, 1982, p. 20.

121. L. Cuesta GutiÉRReZ, «La imprenta en Burgos a través de su historia», Gutenberg-Jahrbuch, 1942-1943, p. 84; A.C. IBÁÑ̃z PéreZ, Burgos y los burgaleses en el siglo XVI, Burgos, Ayuntamiento de Burgos, 1990, p. 419.

122. Algunos ejemplos de 1554-1556 en AGS, CC, libro de relación 10, f. 165r, 175r y 235r.

123. Ejemplos de estos cargamentos en AHPSe, [P]rotocolos [N]otariales de [S] evilla, legs. 2309, 2310, 3394, 8391, etc. 
En definitiva, los Berrio comerciaban principalmente con productos de importación que eran los que en la época podían generar grandes márgenes de beneficios, como explicara en su día Braudel, pero también lo hacían con aquellos característicos del Reino de Granada o propios de la vida cotidiana de entonces. Insistimos, el denominador común de todos ellos es su carácter de ser alta o fácilmente comercializables y, por ello, capaces de alcanzar precios elevados.

$\mathrm{Si}$ la mayor parte de estos productos, y de los valores generados por el comercio de los Berrio, procedían de fuera de las fronteras del Reino de Granada, se impone plantear las preguntas acerca de cuáles eran a su vez sus fuentes de aprovisionamiento y en qué redes de escala internacional se hallaban insertos. Desgraciadamente, los datos que podemos aducir al respecto son todavía muy limitados, aunque parecen apuntar en el sentido de que los Berrio estaban plenamente integrados en el entramado mercantil mediterráneo en que los genoveses habían incardinado, supeditándola, la economía del Reino de Granada desde época nazarita ${ }^{124}$, algo ya apuntado en su día por Bernard Vincent ${ }^{125}$.

La conquista castellana no modificó un panorama dominado por unos genoveses que habían invertido en aquellos sectores especialmente especulativos de la industria europea de la época, tales como la seda, el azúcar, el papel o la imprenta, alcanzando un notable grado de control sobre la seda granadina, aunque tampoco dejaron de tratar con otros productos granadinos como la cera, la grana, la miel o la lana ${ }^{126}$. La continuidad entre las actividades comerciales de los genoveses en el Reino de Granada antes y después de la conquista cristiana ha sido ya puesta de manifiesto por la historiografía. Acabada la guerra, volvieron a afluir a los puertos granadinos las drogas y las especias en las galeazas venecianas que, tras recalar en Orán, arribaban a las playas granadinas en los ultimos meses del año. Rápidamente los genoveses comenzaron a exportar lana por el puerto de Málaga, así como a enviar la pasa y la almendra malagueña a Medina del Campo. Los deudores de los genoveses asentados en Málaga en las décadas posteriores a la conquista reflejan cómo la geografía regional del área malagueña y del interior andaluz (Estepa, Castro del Río, Alcalá la Real y Jaén) fue integrada por éstos en el circuito mercantil peninsular y mediterráneo ${ }^{127}$. Existen indicios claros de que la zona de Jaén, Úbeda y Baeza, con una destacada actividad artesanal a comienzos del Qui-

124. Véase J. HeERs, Gênes au XV $V^{e}$ siècle, Paris, SEVPEN, 1961, pp. 482-498, para la actividad comercial de los genoveses en el mundo ibérico, especialmente Andalucía, durante el siglo XV.

125. B. VINCENT, «Las élites moriscas...», p. 190: "no es imposible que fuesen situados bajo el manto de los grandes mercaderes genoveses".

126. D. Igual Luis y G. NAVARRo EsPINACH, «Los genoveses en España en el tránsito del siglo XV al XVI», Historia. Instituciones. Documentos, 24, 1997, pp. 293-295.

127. J.-E. López de COCA CASTAÑer y M. ${ }^{a}$ T. LÓPEz BeltráN, «Mercaderes genoveses en Málaga (1487-1516). Los hermanos Centurion e Ytalian», Historia. Instituciones. Documentos, 7, 1980, pp. 95-123, los datos mencionados en concreto en pp. 97, 110 y 117. 
nientos ${ }^{128}$, ya entonces presentaba una cierta dependencia respecto de los circuitos genoveses asentados en Granada ${ }^{129}$. El control económico ejercido por genoveses e italianos sobre el territorio se puso también de manifiesto en el hecho de que cuando las especias portuguesas procedentes de Asia comenzaron a penetrar en el Mediterráneo, el trasvase de las mismas hacia Italia lo siguieron realizando fundamentalmente mercaderes italianos (genoveses, milaneses, florentinos $)^{130}$. Estos mercaderes seguían constituyendo entonces el engranaje que conectaba el mundo mediterráneo con el atlántico, de igual modo, aunque en sentido inverso, que durante la primera mitad del siglo XV habían controlado el envío de especiería (y de azúcar o sedas) desde Granada hacia Portugal ${ }^{131}$. Un ejemplo de este tipo de conexiones es la de la compañía florentina de los Botti, presente en Cádiz y Sevilla entre 1519 y 1556, que conectaba con sus agentes el Mediterráneo central con el área peninsular comprendida desde Cartagena, Granada, Málaga y Andalucía Occidental con las islas del Atlántico ${ }^{132}$. En esta área andaluza las redes italianas confluían con los factores portugueses de la factoría de Portugal que, moviéndose entre Málaga, Sevilla o el Puerto de Santa María, abastecían las plazas lusas del norte de África ${ }^{133}$.

El vínculo que conocemos de los Berrio con el sistema mercantil y financiero italiano, y específicamente genovés, se concreta en la persona de Pelegro (o Peligro) de Mayolo (o Mayola). Según una relación de los genoveses que estaban avecindados en la ciudad de Granada en 1575, Pelegro de Mayolo había sido recibido como vecino de la misma hacía doce años, y se le describía como hombre soltero que "tiene cantidad de ganado y trato en otras granjerías", formando parte de la élite genovesa afincada en la ciudad del Darro, de la que también formaban parte Bernaldo Calvo, Miguel Lercaro, Esteban Lomelín, Andrea Espíndola, Pero Gentil, y los hermanos Daniel y Sebastián Quarteroni. Éstos se hallaban plenamente integrados en la ciudad, tanto por el antiguo avencindamiento (hasta 25 años en los dos primeros casos, y desde 1567 en los últimos), como por el matrimonio con mujeres naturales de ella (así Bernaldo Calvo y Daniel Quarteroni), y que en el caso de Esteban Lomelín, miembro de una impor-

128. P.A. Porras ArboledAs, «Los protocolos de Úbeda (1506-1507) y de Baeza (1512). Regesta de su contenido e índices», Cuadernos de Historia del Derecho, 14, 2007, pp. 207-283, especialmente pp. 212-213.

129. Un dato en este sentido: el especiero Rodrigo Mercader, vecino de Baeza, reconocía en octubre de 1512 deber a Antonio Bardola, genovés estante en Granada, 2.800 mrs. por razón de cierto papel que le había comprado y le debía pagar por Santa María de agosto, so pena del doblo (ibid, el dato en p. 241).

130. V. Magalhaes Godinho, Os descobrimentos e a economia mundial, vol. III, p. 181.

131. Idem.

132. A. Orland, «Mercanti toscani nell’Andalusia del Cinquecento», Historia. Instituciones. Documentos, 26, 1999, pp. 365-382.

133. V. Magalhaes Godinho, op. cit., vol. III, p. 270. 
tantísima familia genovesa ${ }^{134}$ y convertido en regidor de Granada en $1559^{135}$, demostraba a las claras el especial interés del capital genovés por enlazar con las élites moriscas al haber contraído matrimonio nada más y nada menos que con una hija de Pedro Granada Venegas (o Venegas de Granada, como se le menciona también $)^{136}$. Parece claro y natural que los Berrio estuviesen relacionados económicamente con los genoveses, abasteciéndose de muchos de sus productos en las redes comerciales de estos. Así, en 1567 Lorenzo de Berrio entregó a Sebastián Quarteroni 1.500 ducados, parte de una obligación de 3.200 ducados ${ }^{137}$. De ahí que durante y después de la guerra reconociesen por poder notarial a Pelegro de Mayolo como su cesionario para el cobro de sus deudas, con el fin de resarcirle asimismo de sus propias deudas ${ }^{138}$, llegando este a actuar judicialmente cuando así lo estimó oportuno ${ }^{139}$. Un dato es muy ilustrativo a este respecto: cuando el 30 de mayo de 1577 el licenciado Velasco presenta una relación de las cantidades debidas a los Berrio que se habían recuperado hasta la fecha, de los 335.485 mrs. cobrados a distintos deudores, el 33,4\% (es decir, 112.056 mrs.) habían sido cobrados por Mayolo, bien directamente, bien, en la mayoría de los casos, a través de Francisco de Espinosa Aliaga en Jaén, Arjona o Castillo de Locubín, entre agosto de 1568 (y especialmente desde abril de 1569, mes en que los Berrio fueron encarcelados ${ }^{140}$ ) y octubre de $1572^{141}$. Según Vincent, a comienzos de los años ochenta, las deudas de los Berrios con diferentes mercaderes genoveses rondarían todavía los 3.000 ducados aproximadamente ${ }^{142}$.

Este tipo de dependencia económica respecto de los genoveses debió ser muy habitual entre la élite mercantil y propietaria morisca, que debía preci-

134. Algunos datos sobre el importante papel financiero jugado por Esteban Lomelín en época de Felipe II en A. Franco SILVA, El Condado de Fuensalida en la Baja Edad Media, Cádiz, Universidad de Cádiz, 1994, p. 131.

135. J.A. López Nevot, La organización institucional del municipio de Granada durante el siglo XVI, Granada, Universidad de Granada y Ayuntamiento de Granada, 1994, p. 111.

136. AGS, CC, leg. 2179. Sobre este enlace, E. SORIA MESA, La nobleza en la España moderna. Cambio y continuidad, Madrid, Marcial Pons, 2007, p. 98.

137. AHPrGr, G-156, f. 580, en B. VINCENT, «Las élites moriscas...», p. 190.

138. En un documento relativo a las deudas de los Berrio, fechado en 14-I-1574, se dice expresamente de Peligro de Mayola, genovés y vecino de Granada, "que a él le debían Lorenço y Melchor de Berrio cierta cantidad de maravedís y para haçelle pagado dellos le habían entregado poder en causa propia y recaudos de deudas que a ellos les debían y que por virtud dello había cobrado algunas cantidades de maravedís de que había dado relación a los del nuestro Consejo de Justicia, y que entre las personas de quien había cobrado..." (AGS, CMCIII, leg. 2470, expte. 8). Existen otros datos documentales que corroboran esta información.

139. Por ejemplo, en diciembre de 1569 contra Pedro de la Cosa, mercader de Villanueva del Arzobispo (AGS, CMC-III, leg. 2774, expte. 1).

140. Vid. infra.

141. AGS, CC, leg. 2180. Relación de los maravedís que Lorenzo y Melchior de Berrio han cobrado después del levantamiento de las debdas que les debian, 30-V-1577.

142. B. ViNCENT, «Las élites moriscas...», p. 190, a partir de AGS, Contadurías Generales, leg. 358. 
samente su riqueza a unas actividades profundamente penetradas por los intereses de los italianos. El caso de la caña de azúcar producida en la costa de Almuñécar lo pone sobradamente de manifiesto: de los cinco ingenios de azúcar confiscados a sus propietarios moriscos (Álvaro Hermes, Alonso Guahrani, Lorenzo el Chapiz, y Álvaro y Alonso Hanine, una nómina harto significativa), los de los dos primeros fueron comprados por los Espínola por $1.376 .000 \mathrm{mrs}$;; de modo paralelo, si el Chapiz y los Hanine habían concentrado en Almuñécar antes de la guerra casi 600 marjales y más de 150 estadales de tierra de caña (el $56,28 \%$ de la tierra de caña de azúcar de propiedad morisca, que convivía con una propiedad de tipo medio y pequeño entre cuyos dueños documentamos asimismo a personajes como Gaspar de Raya), los mercaderes genoveses Vicencio y Octavio Espínola se acabarán haciendo con 216 marjales y 63 estadales, indiscutiblemente la mayor de las propiedades de tierra de caña poseídas por cristianos viejos en Almuñécar después del conflicto bélico ${ }^{143}$.

La relación de los Berrio con los genoveses no debe hacernos pensar que los hermanos moriscos eran meros agentes de aquellos. No lo eran. La magnitud de sus negocios hacía que trabajasen también en relación con los que eran corazones económicos de Castilla, Sevilla y Medina del Campo, en donde compraban y vendían, y con una de las grandes familias castellanas de las finanzas de entonces, los Ruiz ${ }^{144}$. En 1555, Lorenzo Pérez de Berrio tenía obligaciones de varios mercaderes castellanos que contrataban en Medina (dos de Toledo, uno de Villalón y otro de Villacastín) y del francés Jusepe Osandón, vecino de Thiers y muy activo en el tráfico entre Francia y Medina del Campo durante su largo periodo de actividad (1555-1591) ${ }^{145}$. Parece que la principal actividad de los mercaderes granadinos en Medina del Campo haya sido la venta de seda ${ }^{146}$, también de los Berrio, de los que conocemos la venta de dos cajas de sedas en 1567 a Hernández de Baeza, mercader de sedas vecino de Medina, que por una cédula quedó en pagarles por ellas 166.979 mrs. "en pagos de feria" de octubre de ese mismo año, si bien la cédula quedó finalmente en poder de Simón Ruiz ${ }^{147}$. También los Berrio compraban en Medina: en 1567 hallamos a Lorenzo y a Melchor en la larguísima lista de los que debían dinero a Vítores Ruiz $^{148}$; en 1568 Melchor de Berrio forma parte de una lista de ocho personas (hay otros dos granadinos, Pablos Centeno y Gonzalo Jaén) que deben al len-

143. M. ${ }^{a}$ M. BirRIEL SAlCEDO, «Ventas de bienes confiscados a moriscos en la tierra de Almuñécar», Chronica Nova, 16, 1988, pp. 39-53.

144. H. LAPEYRE, Una familia de mercaderes: los Ruiz, Valladolid, Junta de Castilla y León, 2008.

145. A. Rojo VeGA, Guía de mercaderes y mercaderías en las ferias de Medina del Campo. Siglo XVI, Valladolid, Fundación Museo de las Ferias con la colaboración de la Diputación de Valladolid, 2004, pp. 158 y 335.

146. Ibid, p. 233.

147. AGS, CMC-III, leg. 2757, expte. 8.

148. A. Rojo VeGA, op. cit., p. 28. 
cero de Medina Francisco del Castillo ${ }^{149}$; en otro protocolo medinense de 1570 volvemos a topar con Melchor de Berrio entre las obligaciones del burgalés Andrés Enríquez ${ }^{150}$; y todavía en los primeros años ochenta, Hernando de Castro y Francisco Rodríguez, mercaderes vecinos de Medina del Campo, reclamaban como acreedores de Lorenzo de Berrio más de 280.000 maravedís, que intentaban recuperar en lo habido asimismo del cobro de las deudas debidas a los Berrio y cobradas por el licenciado Velasco ${ }^{151}$. En cualquier caso, quizás lo más lógico es pensar que los Berrio se relacionaban con Medina fundamentalmente por su función de feria de cambios y para vender sedas, aparte de para comprar algunos productos, quizás preferentemente textiles. No creemos que los Berrio acudiesen a Medina a abastecerse de especias, por más que existan testimonios de que en ella abundaban las procedentes de Portugal ${ }^{152}$.

Sevilla fue otro de los puntales del negocio de los Berrio, como lo indica el volumen de deuda reclamada en ella, especialmente al mercader Andrés López ${ }^{153}$, o que en la escritura de 1555 en que Lorenzo Pérez de Berrio saldaban sus cuentas con el también mercader granadino Hernán López en virtud de una cédula de 101.200 mrs. (librada en 12-III-1554) a su hermano Diego López, estante en Sevilla, este aparezca de alguna manera como dependiente de Bautista Buron ${ }^{154}$, miembro de una familia genovesa afincada en Sevilla desde hacía algún tiempo que se acabará integrando en su oligarquía urbana hasta conseguir el ennoblecimiento ya en el siglo XVII ${ }^{155}$. Otras conexiones internacionales de los Berrio se habrán de aclarar en el futuro ${ }^{156}$.

La conexión financiera con Medina del Campo, capital de los cambios castellanos, era necesaria habida cuenta de la complejidad de la malla de préstamos y deudas tejida por la actividad mercantil de los Berrio, desarrollada

149. Ibid, p. 183 y 288.

150. Ibid, p. 188.

151. AGS, CC, libro de cédulas 258, f. 107r-108r. Sobre Velasco, vid infra.

152. Así lo afirman Godinho y otros autores. Sobre especias en Medina, cf. A. Rojo VEGA, op. cit., pp. 43-45, cuyos datos bastan para corroborar la conexión portuguesa de Medina así como la relativa importancia de la misma, tanto en términos de volumen como de dinero.

153. AGS, CMC-III, leg. 3068, expte. 31; un intento de cobro al mismo en septiembre de 1567 en AHPrGr, G-158, f. 1167r. 14-IX-1567.

154. AHPrGr, G-91, f. 757r-v. Granada, 1-VII-1555.

155. J. Díaz de Noriega y Pubul, La Blanca de la Carne en Sevilla, Madrid, CSIC, 1975, vol. I, p. 247.

156. Una interesante, por ejemplo, es la que podría existir con el comercio griego y sus ramificaciones en Andalucía, un tema bastante desconocido. Sabemos que un tal Pedro de Val Saboyano, vecino de Jaén, debía dinero a los Berrio por impagos desde 1567 (AGS, CMC-III, leg. 3228, expte. 11). Quizás tenga que ver con Juan Saboyano, trabajador, "natural de Santa Maura, en Levante, en la Grecia, residente en Jaén", procesado por la Inquisición en los años ochenta, a causa de distintas irreverencias, blasfemias y comentarios de sabor islámico (R. Gracia BoIX, Autos de fe y causas de la Inquisición cordobesa, Córdoba, Diputación Provincial de Córdoba, 1983, pp. 229-230). Del papel de los armenios, más tardío pero similar al de los griegos como contacto con el Mediterráneo oriental, se ocuparon en su día Braudel y Domínguez Ortiz. 
habitualmente mediante la venta con pago aplazado, que se solía satisfacer bien en tiempos breves (uno o dos meses) o bien en una determinada feria de tal o cual localidad por los tiempos que solían ser comunes en estos asuntos (como el Viernes Santo, San Andrés, Nuestra Señora de Agosto, San Miguel, Navidad, Carnestolendas, etc.). Un estudio exhaustivo de la copiosa información que sobre el sistema de pagos a los Berrio se conserva en los legajos citados de la Contaduría Mayor de Cuentas de Simancas, así como en los protocolos granadinos y en los de las localidades jiennenses donde se desarrollaba la mayor parte de su negocio, arrojaría notable luz sobre un tema tan desconocido para el siglo XVI como es el sistema financiero en Andalucía oriental y sus relaciones con otras regiones castellanas. El recurso masivo y habitual al crédito en un territorio tan amplio provocaba a los Berrio continuas y casi sistémicas dificultades para cobrar las cantidades que les debían sus compradores. Por ello, y de modo paralelo a la red de arrieros de la que se servían para abastecer a sus clientes, los Berrio desarrollaron un auténtico sistema de cobro. Una muestra de esta actividad, continuada y habitual insistimos, la tenemos en el poder que Melchor de Berrio otorgó en 1567 a Gabriel Ramírez, vecino de Granada, para que cobrase unos $131.000 \mathrm{mrs}$. de ocho vecinos de Ronda (entre los que contamos un tintorero, un platero y un mercader) y otros $26.900 \mathrm{mrs}$. del mercader Alonso Fernández, vecino de Vélez-Málaga ${ }^{157}$. El trabajo de Ramírez fue infructuoso, al menos en parte, pues seguimos encontrando entre los deudores de los Berrio en 1573 a varios de ellos, bien es cierto que por cantidades menores de las que debía cobrar Ramírez en $1567^{158}$. Es evidente que el carácter en ciernes del moderno capitalismo practicado por los Berrio conllevaba unos enormes riesgos que no siempre se era capaz de conjurar ${ }^{159}$. En este sentido, la actuación financiera de la Corona parece que tampoco dejó de afectar a los Berrio. Parece probable que sus negocios también se vieran afectados por la bancarrota decretada en 1557, que, como todas las operaciones de este tipo, desquiciaban el sistema general de cambios y pagos y obligaban, por sus efectos en cadena sobre el entramado financiero y mercantil, a renegociar las deudas y redefinir los tiempos de su abono. Pensamos como posible que con dicha bancarrota tenga relación el hecho de que de la lista de 219 deudas reconstruidas por el contador Martín Pérez de Arriola en 1573 para las 49 poblaciones que hemos documentado, casi una tercera parte de ellas hacen referencia a que son resto de caja de 1557 y de deudas anteriores. Así, el factor político afectaba gravemente la modernización y crecimiento del sistema financiero castellano, en el que se hallaban plenamente integrados Lorenzo y Melchor de Berrio.

157. AHPrGr, G-156, f. 46r y 50r-v. Granada, 3 y 5-VII-1567.

158. Me refiero al boticario Diego Delgado, al mercader Cristóbal Hernández y a Alonso Calderón, y quizás también a Juan de Alhama (¿o Ahumada?). Cf. AGS, CMC-III, leg. 2951, expte. 1.

159. Es difícil completar una nómina de los encargados por los Berrio para cobrar sus deudas. Uno de ellos es Pedro Navarro, vecino de Granada, encargado de cobrar en 1567 en Sevilla (AHPrGr, G-158, f. 1167r), Baeza (AHPrGr, G-156, f. 170v), La Guardia, Mengíbar y Huelma, así como los condes de Santisteban, que debían a los Berrio 110 ducados (AHPrGr, G-156, f. 168r-169r). 
¿Cuál fue el resultado de toda esta ingente actividad económica? Si creemos las indagaciones oficiales realizadas después de la guerra, los bienes raíces de Lorenzo y Melchor de Berrio habrían consistido en dos huertas (una era la de El Albeçana, "en lo alto del Albayzin") y dos casas en el Albaicín de Granada (quizás una de ellas sería la tienda que tenían en la cerería de Granada), así como un molino de pan en el Genil, todo tasado en 3.500 ducados, a los que habría que añadir 8.969.323 mrs. (unos 24.000 ducados) de las deudas comentadas y pendientes de cobro ${ }^{160}$. Falta, evidentemente, el dinero líquido de los Berrio, que lógicamente éstos habrían puesto a buen recaudo lejos de las garras de la monarquía, imposible de calcular pero indudablemente mucho, y que les permitiría reiniciar una nueva vida después de la guerra. En 1577, necesitando el corregidor de Ciudad Real información sobre el perfil de Lorenzo de Berrio y Gaspar de Raya, entonces residentes en Toledo, recabó un dato que no debemos considerar en ningún caso como desorbitado: "dizenme que estos Berrio y a Raya son muy ricos y que vale su hazienda más de 40.000 ducados" ${ }^{\prime 161}$. Si tenemos en cuenta lo que sabemos acerca del patrimonio de Gaspar de Raya ${ }^{162}$, la inmensa mayoría de ese dinero correspondía a los Berrio. Entendemos como muy relevante para la historia de los moriscos la consideración de la existencia de enormes capitales dentro de la minoría en el periodo 1570-1610.

\section{LOS AÑOS CRÍTICOS DE GRANADA Y LA LUCHA POR LA RECUPERACIÓN DEL PATRIMONIO (1569-1577)}

Es evidente que el estallido de la rebelión el día de Navidad de 1568 tuvo unas consecuencias nefastas sobre la densa, extensa y compleja trama mercantil de los hermanos Berrio, dificultando su funcionamiento, paralizando las operaciones, e impidiendo el cobro de las numerosas deudas en una geografía tan dispar. Para empezar, los Berrio habrían sido encarcelados el 6 de abril de $1569^{163}$

160. AGS, CC, leg. 2178. Granada, 5-XII-1576.

161. AGS, CC, leg. 2179. Ciudad Real, 9-VI-1577.

162. Gaspar de Raya acabó consiguiendo la devolución de 3.600 ducados por su hacienda; su hija Florencia de Raya llevó en su día una dote por valor de 400.000 mrs. (AGS, CC, leg. 2190, cf. R.M. PÉrez García y M.F. Fernández Chaves, op. cit., en prensa).

163. Esta es la fecha que proporciona un informe de 5-XII-1576 enviado al rey sobre los Berrio, en el que se le explica su caso (AGS, CC, leg. 2178). Sin embargo, otros documentos señalan, quizás con más acierto y lógica, hacia que Lorenzo de Berrio habría sido encarcelado en enero de 1569. Así, el 6 de mayo de 1569, Lorenzo pedía que se le liberase porque "a cuatro meses que estoy preso sin culpa [...] porque recibo mucho perjuicio" (Archivo de la Alhambra, L-782-113). Y el 10 de octubre de 1569, junto con otros prohombres moriscos encarcelados en la $\mathrm{Al}-$ hambra (Jerónimo de Palacios, Miguel López, Lorenzo Hernández y Pero López Çaybona), Lorenzo de Berrio presentaba una petición solicitando una mejoría en las condiciones de prisión (la vuelta al aposento alto de la cárcel) diciendo que "estamos presos sin culpa nueve meses" (Archivo de la Alhambra, L-78-2-47). 
en el marco de la "información general" que se hizo "contra todos los moriscos" del Reino de Granada. Durante su prisión y proceso, numerosos testigos testificaron en su contra implicándolos directamente en la conspiración que condujo al levantamiento de la Navidad de 1568, acusándolos de haber estado preparados para rebelarse en el Albaicín, de participar en actos violentos contra cristianos viejos, etc. ${ }^{164}$. Las acusaciones eran tan graves, que ambos hermanos

164. El resumen de la causa contra los Berrio enviado a Felipe II y fechado en Granada el 5-XII1576 dice así: "lo que en el negocio pasa es que al principio de la rebelion deste Reyno se hizo ynformacion general contra todos los moriscos del y della resultaron culpados Lorenço y Melchor de Berrio su hermano, y la culpa particular que ovo contra el Lorenzo de Berrio es que dize un testigo que en la tienda que tenia en la cereria de Granada y en una huerta suya que dizen El Albeçana ques en lo alto del Albayzin se juntauan el dicho y otros y hazian concilios / y otro testigo dixo que todos los moriscos principales del Albayzin sabian el levantamiento y que uno dellos era el Lorenzo de Berrio el qual dize escribio de su mano las personas que avian de benir por capitanes de los lugares de la Vega a dar favor al Albayzin / otro testigo auer oydo dezir que en casa del Lorenço de Berrio se avia de alçar por Rey a don Fernando de Valor y otro dize que auia oido dezir a moriscos que Lorenzo de Berrio auia ydo al Alpujarra a tratar del levantamiento / y dize otro testigo mujer que estando captiua oyo dezir en el Alpujarra a los moriscos que auian alçado por Rey al Lorenzo de Berrio / otros testigos dizen que la propia noche que los moriscos entraron en Granada a levantar el Albayzin estauan el Lorenço de Berrio y otros a media noche vestidos y que diziendoles que no parecia bien estar tantos juntos auiendo la nueva que avia del Alpujarra Respondio que estaban jugando / otro testigo dijo que ocho dias antes de navidad andaua don Fernando de Valor por el Albayzin con el Lorenzo de Berrio / y dos testigos dizen que andando rondando por el Albayzin como guardas alrededor de Pascua de Navidad hablaron con el Lorenzo de Berrio en su casa algunos moriscos principales / demas de los dicho esta yndiciado / y asi Melchior de Berrio su hermano de auer savido y entendido el levantamiento mucho antes que sucediere. La culpa particular de Melchior de Berrio es que dize un testigo que en las camaras altas que estan dichas de la tienda de Lorenzo de Berrio su hermano y en la dicha huerta de Albeçana se juntaban moriscos a hazer cauildos entre los quales estaua el Melchor de Berrio / y hablaban en secreto y se guardaban deste testigo y que siempre tuvo mala sospecha dello / otros dos testigo dizen que por el mes de diziembre del año del levantaniento encontraron una noche a los dos hermanos Berrios / y quel Lorenço de Berrio les rogo que llevasen al Melchor de Berrio su hermano al molino de Daniel el Zeneti su suegro / y que asi lo llevaron y dexaron y que bajaron a abrir la puerta del molino a oscuras y que oyeron dentro gran ruydo / quatro testigos dizen que estando en el cortijo Descuçar ques del suegro deste Melchor de Berrio un Pero Rodriguez y otros cristianos viejos trillando cierto pan que alli auian segado, llego el Melchor de Berrio y les amenazo diziendo que se lo avian de pagar y echandose mano a las barbas porque venian a trillar su pan y que podria ser que no volviesen a Escuzar por su pan y que antes del lunes por justicia o sin ella se lo avian de pagar y que volviendo estos christianos viejos a cargar el pan que tenian aventado avian salido dos mangas de moriscos y los cautivaron y llevaron los bagajes cargados de pan / y que del dicho cortijo Descuçar andaua en la sierra con los moriscos revelados dos negros y dos moriscos criados del Melchor de Berrio y del Lorenzo su hermano, a los quales los moros no llegaron y que por esto se entendio que era traycion quel Melchor de Berrio les tenia armada / y seys testigos dizen que tienen por cosa cierta que el Melchor de Berrio fue a la sierra con su suegro y despues se volvio y dizen mas que le vieron un dia en la puerta de una sierra hazia el cortijo dicho en un caballo con lanza y adarga y otro hombre de a caballo con el que entendieron que era su suegro y con otros moros de a pie y le temieron y se recogieron por lo qual dizen los testigos que tienen por cierto quel Melchor de Berrio fue en el captiuerio del dicho Pero Rodriguez [...]" (AGS, CC, leg. 2178). El testigo que señala a la casa de Lorenzo de Berrio como el lugar donde Hernando de Córdoba habría sido elegido como líder de la revuelta era un esclavo negro (Bernardino) del padre de este, Antonio de Córdoba (B. VINCENT, «Las élites moriscas...», pp. 195-196, que remite a Archivo Zabálburu, leg. 158). 
fueron torturados por la justicia con objeto de conducirlos a declarar la verdad sobre el asunto. Sin embargo, ambos superaron la brutal prueba y no reconocieron ninguna de las acusaciones, "hicieron probanzas tachando los testigos" hasta conseguir una victoria relativa: Lorenzo de Berrio fue condenado a pagar 400 ducados, y Melchor de Berrio a pagar 200 ducados y otros tantos para el rescate de un cristiano viejo cautivo llamado Pedro Rodríguez, en cuyo cautiverio habría tenido participación según los testimonios reiterados por diferentes testigos. Además, fueron condenados a destierro a cincuenta leguas de Granada: el 14 de octubre de 1572 fueron llevados a Toledo ${ }^{165}$. Pena económica y de destierro que traducía la no posibilidad de la declaración judicial de su culpabilidad, pero sí la sospecha con casi certeza de las autoridades cristianas: por ello, y a diferencia de otros moriscos granadinos, a los Berrio no se le permitió permanecer en el Reino de Granada ${ }^{166}$. A partir de ese momento comenzaba para ellos la batalla legal para recuperar su patrimonio desde el exilio castellano.

La provisión real de 24 de febrero de 1571 de confiscación de todos los bienes de los moriscos del Reino de Granada en base a sus gravísimos delitos de "lesae divinae et humanae majestati" amenazó, finalmente, con arrancar a los Berrio su emporio comercial. La confiscación o incorporación a la Corona afectaba a "todos sus bienes muebles, y raizes y semovientes, derechos y acciones en cualquier manera que les perteneciesen"; además, la provisión real ordenaba a todas las personas que hubiesen dejado deudas de dinero pendientes de pagar a los moriscos "por obligaciones, contratos, conocimientos" o por otras "escripturas" y "recaudos", que las declarasen en el plazo de treinta días; lo mismo se disponía para las personas sobre cuyos bienes hubiese censos perpetuos, al quitar o de cualquier tipo. Quedaba patente la voluntad de la Corona de apropiarse de todo lo que fuera de los moriscos, y para ello era consciente de la necesidad de generar unos adecuados instrumentos documentales de registro y gestión de tan enorme patrimonio. Sin embargo, la provisión de 24-II-1571, en un acto de justicia propia de la persona del rey que usa de "gracia y gratificación", preveía también la indemnización a aquellos moriscos que resultasen finalmente "no culpados", concediéndoles la "justa recompensa, satisfacción, y refacción de lo que los dichos sus bienes valieren"167.

165. El relato anterior se basa en AGS, CC, leg. 2178.

166. B. VINCENT, «Los moriscos que permanecieron en el reino de Granada después de la expulsión de 1570", Andalucía en la Edad Moderna: economía y sociedad, Granada, Diputación Provincial de Granada, 1985, pp. 267-286; y R.M. Pérez GARCíA, «Moriscos, razones y mercedes ante el poder del Rey en el Reino de Granada después de 1570», Ámbitos. Revista de Estudios de Ciencias Sociales y Humanidades, $2^{a}$ época, 22, 2009, pp. 35-50.

167. El texto de la provisión de 24-II-1571 fue publicado en M. BARRios AgUILERA y M. ${ }^{a}$ M. BirRIeL SALCEDO, La repoblación del reino de Granada después de la expulsión de los moriscos, prólogo de Bernard Vincent, Granada, Universidad de Granada, 1986, pp. 183-188. Un completo repaso por las referencias bibliográficas y las problemáticas legales anexas a esta norma, en M. ${ }^{\mathrm{a}} \mathrm{M}$. BIRRIEL SALCEDO, «Ventas de bienes...», pp. 39-553, donde se hace un estudio del caso. 
Lógicamente, la confiscación también afectó a los Berrio: se les secuestraron los bienes muebles y se tomó posesión de los raíces en nombre del rey. Sin embargo, finalmente, al no haberse podido probar su culpabilidad, las sentencias ordenaron la devolución de sus bienes muebles una vez hubieran satisfecho el pago de las penas impuestas y dado fianzas suficientes para satisfacer a sus acreedores, fundamentalmente con el objeto de que pudieran hacer frente a las penas y a sus deudas. Dichos bienes muebles les fueron devueltos "al tiempo que fueron sueltos de la cárcel y prisión en que estaban" ${ }^{168}$, y se entregaron a Pedro de la Fuente, escribano de la Chancillería de Granada, "las obligaciones y recaudos que tenían contra sus deudores", con el objeto de que pudieran utilizarse para proceder a su vez al pago a sus acreedores ${ }^{169}$.

El estudio detallado de la documentación económica de los Berrio, de sus libros de caja y de distintas confesiones tomadas a los mismos durante "el proceso" $^{\prime 170}$, permitió al contador Martín Pérez de Arriola la elaboración de las listas de deudores que hemos presentado y comentado anteriormente, firmadas todas ellas (al menos las que conocemos) entre octubre y noviembre de 1573. Con esta herramienta era posible ya proceder a cumplir los deseos expresados por el rey en la provisión de confiscación de 24-II-1571. Así, el 22 de noviembre de 1573 se procede a formalizar una comisión para el cobro de las deudas de los Berrio en todos aquellos lugares donde estuviesen pendientes de cobro. La provisión que ordena dicha comisión (dada en Granada en tal fecha) encarga el cobro a las justicias locales en aquellas poblaciones de fuera del Reino de Granada y a los administradores de los partidos en las localidades del mismo, todo según una instrucción extremadamente precisa, que acompaña siempre a la orden de ejecución de la comisión, y que se suele adaptar a las peculiaridades tipológicas de los deudores a localizar, que habrían de ser requeridos para pagar en un plazo de tres días. El control documental de todo el dinero cobrado quedaría centralizado en Granada por el contador Martín Pérez de Arriola, y el metálico debería, finalmente, ser conducido a Granada y entregado al receptor de los bienes confiscados a los moriscos ${ }^{171}$.

Esta comisión, a pesar de lo ambicioso de su planteamiento, y de todo el dispositivo puesto en marcha para conseguir el cobro de las deudas, dio escasos resultados. Del monto total de 8.969.323 mrs. de deuda calculado por el contador Martín Pérez de Arriola en octubre-noviembre de 1573, en diciem-

168. Que suponemos hubo de ser en octubre de 1572, momento en que fueron deportados a Toledo.

169. AGS, CC, leg. 2178. Cédula de 11-IV-1574.

170. Referencia, por ejemplo, a la confesión tomada a Lorenzo de Berrio en Granada en 1-IX-1571 sobre las deudas en Huéscar, en AGS, CMC-III, leg. 3097, expte. 6.

171. Una copia de esta provisión de 22-XI-1573 (de las muchas que se conservan), dirigida a las autoridades de Albánchez, en AGS, CMC-III, leg. 3045, expte. 18. 
bre de 1576 sólo se habrían cobrado, según los tres jueces ${ }^{172}, 208.143 \mathrm{mrs} .{ }^{173}, \mathrm{y}$ en mayo de 1577 (según el licenciado Velasco) 335.485 mrs. correspondientes a Jaén, Pegalajar, La Guardia, Martos, Porcuna, Arjona y Arjonilla, y Alcalá la Real ${ }^{174}$. Los informes elaborados por las autoridades locales competentes en cada población registran pocos casos en que se llegaran a pagar las deudas supuestamente pendientes de pago a los Berrio, normalmente por fallecimiento, ausencia o desaparición de los deudores, o por alegación de éstos explicando ya haberlas pagado y presentando la documentación justificativa. Esto originó, conforme establecían las Instrucciones remitidas para el cobro, una multitud de pleitos que, si bien debían acabar aclarando cada caso particular, dilataron y paralizaron inevitablemente todo el proceso.

Los Berrio, por su parte, no renunciaban a su hacienda perdida. Tras su deportación a Toledo, y en algún momento de 1573 o comienzos de 1574, elevaron una petición al rey pidiendo la devolución de sus bienes raíces. Para ello alegaban su no culpabilidad, haber gozado siempre de las preheminencias de cristianos viejos y conforme a ello portado armas, así como los servicios prestados a la Corona. Amargamente se quejaban de que sus bienes raíces habían sido confiscados en nombre del rey, y que "sin embargo de la ynjusta y larga prision que tuvieron y gran perdida y menoscabo de sus haziendas y personas, se ha querido y quiere poner dificultad sobre que no se les han de entregar los bienes rayzes que dexaron en esa dicha ciudad y Reyno [de Granada]"; sin embargo, para los Berrio "lo que peor es" era el hecho de que se estuviesen cobrando las deudas que se les debían dentro y fuera del Reino de Granada, cuando "la cobrança y dispusicion dellas" les pertenecía por haberles quedado libertad para ello, y que si entregaron las obligaciones a Pedro de la Fuente fue sólo para "seguridad de sus acreedores" y no para que se cobrasen ni en nombre ni en beneficio del rey ${ }^{175}$. Ante la petición de los Berrio para recuperar sus bienes raíces y el importe de sus deudas, el rey, por la citada cédula de 11 de abril de 1574, ordenó hacer un informe sobre el asunto del que finalmente se encargaron los tres jueces, que lo concluyeron y firmaron en Granada más de dos años y medio más tarde, el 5 de diciembre de 1576, mostrándose contrarios a la devolución de sus bienes raíces y deudas a los Berrio tanto "por aver sido

172. Recordemos que el Tribunal de los Tres Jueces fue el encargado de juzgar en todo aquello referente al delito de la rebelión de los moriscos, incluido lo relacionado con la incautación de su patrimonio, M. ${ }^{a}$ M. BIRRIEL SALCEDO, «Las instituciones de la repoblación», en M. BARRIOS AguILERA (ed.), Historia del Reino de Granada, vol. II, pp. 658-662.

173. AGS, CC, leg. 2178. Vid. infra.

174. AGS, CC, leg. 2180. Relación de los maravedís que Lorenzo y Melchior de Berrio han cobrado después del levantamiento de las debdas que les debian, 30-V-1577. A estos datos añade el licenciado Velasco no sin cierta ambigüedad: "entiéndese que en Ubeda y Baeza y Sevilla y en la ciudad de Ronda y Marbella y en esta ciudad de Granada y otros lugares se cobraron, con cuydado despues del levantamiento e yncorporacion general".

175. AGS, CC, leg. 2178. Cédula de 11-IV-1574. 
estos culpados en el trato y levantamiento deste Reyno ${ }^{176}[\ldots]$ como por el inconveniente y consequencia que se daría a otros desta calidad"177. Aunque no conocemos la decisión final adoptada por Felipe II, todo parece señalar que no se accedió finalmente a la petición de los hermanos Berrio ${ }^{178}$.

Los Berrio no eran sino una de las numerosas familias de la élite morisca granadina que en los años siguientes a la guerra intentaron recuperar sus bienes o las indemnizaciones correspondientes elevando sus peticiones a un rey enojado con su comunidad, a la que había castigado duramente ${ }^{179}$. A la par que ellos, y en aplicación de lo previsto por la provisión de confiscación de febrero de 1571, los delegados reales pretendían a su vez apurar el proceso de confiscación hasta sus últimas consecuencias, saldando el complejo entramado de las deudas debidas a y por los moriscos granadinos. En el caso de las cantidades adeudadas por cristianos viejos a moriscos granadinos, más allá de cifras concretas de las que carecemos aparte de datos parciales y concretos, podemos afirmar que eran tan importantes como difíciles de cobrar.

Es ésta la causa de que el 30 marzo de 1577 el rey autorice la comisión del licenciado Gaspar de Velasco (fiscal de su majestad en el Consejo de Hacienda y Justicia que residía en la ciudad de Granada) con el objeto de cobrar las deudas que los cristianos viejos debían a los moriscos, especialmente las correspondientes a los ricos mercaderes del Albaicín, como los hermanos Berrio, los Cárdenas y el Ferí. La causa de la comisión, que se alargó hasta marzo de 1578, era clara: "aunque es mucho lo que se debe, es muy poco lo que se ha cobrado", porque "todos los deudores dizen que no deben cossa ninguna más de lo que co[n]stare deber, por recaudos bastantes los pagarán, y porque no los había ay no se les apremió a ello". Además de por las cuantías, la cuestión era importante por la "calidad" de los deudores: el duque de Sesa, el marqués de Villanueva, el presidente de Galicia, el alcalde mayor de Galicia, el inquisidor Andrés de Álava, los oidores de la Chancillería, etc. En el debate previo a la concesión de la comisión a Velasco, se llegó incluso a proponer que se diera vara de justicia a uno de los Berrios, a uno de los Cárdenas y al Ferí para que ellos, como conocedores directos de las deudas y los deudores, "entendiesen en la cobrança". La no materialización de esta idea condujo directamente a la creación de la co-

176. A pesar de lo dicho más arriba acerca del resultado de sus procesos, esta afirmación revela cómo de manera interna las autoridades los consideraban verdaderamente culpables.

177. AGS, CC, leg. 2178. Granada, 5-XII-1576.

178. Así lo indica, por ejemplo, el hecho de que a comienzos de los años ochenta una parte de las deudas de los Berrios con mercaderes genoveses fuera cubierta por la propia Corona, en la medida de las deudas debidas a los hermanos moriscos por particulares (B. VINCENT, «Las élites moriscas...», p. 190, remitiendo a AGS, Contadurías Generales, leg. 358), sin duda a causa de que era la Corona quien finalmente se había quedado con el valor de las deudas de los Berrio.

179. Sobre este complejo problema, véanse M.F. FERNÁNDEZ CHAVES, «La súplica al Rey y la supervivencia de las élites moriscas granadinas después de 1570: el caso de doña Brianda de Venegas», en prensa, y R.M. PÉREZ GARCÍA, op. cit., pp. 35-50. 
misión del licenciado Velasco, cuyo desarrollo se vio obstaculizado por la oposición de diversas oligarquías locales (de Guadix, Huéscar o Fiñana) ${ }^{180}$.

Dejando a un lado las dificultades que Velasco sufría de modo inherente a la naturaleza de su comisión (otorgada por un corto periodo de tiempo, y que se fue renovando hasta su duración final cercana al año), parece claro que consiguió desatascar el punto muerto en que había quedado la cobranza de las deudas debidas a los moriscos. En una Relación del fiscal Velasco dada el 14 de septiembre de 1577, este informaba que en Jaén, Córdoba, Baena y los lugares de la Orden de Calatrava hizo 61 procesos e informaciones sumarias, con un resultado de más de 5.000 ducados; en Pegalajar, La Guardia y la ciudad de Jaén, de la comisión de 22-XI-1573 y el memorial del contador Arriola, encontró 46 procesos pendientes de resolver desde fines de aquel año, que sustanció, ejecutando algunos con el resultado de cobro de unos 300 ducados; en Martos, Arjona, Arjonilla y Porcuna, Velasco resolvió otros 24 pleitos relativos a las deudas de los Berrio, ingresando otros 100.000 mrs.; de Baena, finalmente, el fiscal daba cuenta de la enorme deuda contraída, y reconocida, por el duque de Sesa a favor de los Cárdenas, otra familia de ricos moriscos, que superaba los $5.166 .000 \mathrm{mrs}$., y que daría lugar a un grueso pleito en tanto que posteriormente el duque había arrendado su estado al genovés Esteban Lercaro $^{181}$. También fue complicada para Velasco la resolución de la deuda reclamada por Hernán López el Ferí a la marquesa de Villanueva del Fresno (que según el memorial presentado por el morisco en el Consejo de Población ascendía a 995.285 mrs.) y a otros miembros de la familia Portocarrero (don Pedro, don Alonso y don Juan) que sumaban otros 396.000 mrs., pues la documentación aportada por el Ferí no era clara, faltaban algunos libros y la marquesa, aunque reconocía haber recibido sedas del mercader granadino antes de la guerra, no se acordaba de la cantidad ni precio ${ }^{182}$.

En torno a 1576-1577, la batalla jurídica de los Berrio por recuperar su patrimonio inmueble y sus deudas estaba perdida. En ello había jugado un papel clave su poco clara trayectoria personal de fidelidad al rey, y la decidida voluntad y acción política de este de aplicar el castigo oportuno a los moriscos rebeldes y traidores. Sin embargo, Felipe II no se había desentendido en absoluto de la cuestión morisca, por más que acuciantes problemas en otros frentes y latitudes reclamasen su atención. Al contrario, sus necesidades económicas le obligaron a interesarse de nuevo en apurar al máximo las posibilidades económicas derivadas de la confiscación de los bienes de los moriscos granadinos. No obstante, los rendimientos de la operación dejaban que desear. Es en este cruce de intereses entre el monarca y los ricos mercaderes moriscos donde

180. Para lo relativo a la comisión del licenciado Velasco, $M^{\mathrm{a}}$. M. BIRRIEL SALCEDO, «Nuevos datos...», pp. 51-52.

181. AGS, CC, leg. 2180.

182. Las cartas relativas a este asunto en AGS, CC, leg. 2181. 
los Berrio optarán decididamente por jugar la baza política en clave de intermediación (fiscal) como vía de recuperación económica y reivindicación social en el seno de su comunidad.

\section{LOS COMIENZOS DE LA MEDIACIÓN POLÍTICA: CA. 1576-1580}

Antonio Domínguez Ortiz y Bernard Vincent señalaron en su día la importancia del "sentimiento" por la vuelta a Granada como un factor capital en la historia posterior al exilio de los moriscos ${ }^{183}$, y recientemente el mismo Vincent ha vuelto sobre el particular destacando entre otros el papel que los hermanos Berrio, asociados al también mercader granadino Gaspar de Raya, tuvieron en la promoción de esta idea entre los moriscos so color del éxito de unas supuestas negociaciones con la Corona. Todo comenzó en 1577 en Ciudad Real, repitiéndose las alteraciones en la comunidad morisca debido a la propagación de los rumores y las negociaciones con la Corona también en 1579 y en 1584, sin que se obtuviera ningún resultado, hasta que el desastre de la Armada en 1588 llevó a Felipe II a buscar nuevas fuentes de financiación, que además de los millones estaban constituidas por otros recursos como el servicio morisco de $200.000 \mathrm{du}-$ cados cuyas negociaciones determinantes comenzaron en $1589^{184}$.

El servicio se proponía a cambio de la vuelta selectiva de destacados miembros de la comunidad morisca, y la estancia permanente de una gran mayoría en tierras castellanas, consagrándose así una división profunda entre "buenos" y "malos" moriscos, que no se refrendará legalmente hasta 1584 como veremos. Esta división tiene su origen en la inclusión del morisco entre los rebelados o los "de paz", con su razón de ser última en la posición jugada durante la guerra de las Alpujarras, y que iba a presidir las relaciones de los moriscos con sus dominadores cristiano viejos hasta la expulsión de $1610^{185}$.

Tanto en 1577 como en las negociaciones posteriores aparece de manera continuada Lorenzo de Berrio ${ }^{186}$ (Gaspar de Raya había muerto en 1583 como muy tarde), a quien podemos suponer arquitecto de este plan. En la década de 1580, el ascendiente de los miembros más acaudalados de la nación morisca estaba desplazando al de las élites de la sangre, y la idea de una rebelión violenta que marcase la ruptura plena con el orden castellano y la obediencia a los

183. A. Domínguez Ortiz y B. Vincent, op. cit., pp. 60-61.

184. B. VINCENT, «Los moriscos granadinos y la monarquía», en J.I. ForTEA, J.E. GELABERT (eds.), Ciudades en conflicto (siglos XVI-XVIII), Valladolid, Junta de Castilla y León, Marcial Pons, 2008, pp. 163-179, y aquí, pp. 166-173.

185. Como se desprende de la actuación personal de Alonso del Castillo o Miguel de Luna y otros acontecimientos analizados por M. GARCíA-ARENAL y F. RodríguEz MEDIANO, op. cit., vid. los capítulos correspondientes a ambos traductores.

186. Como ya señalara B. VINCENT, «Los moriscos granadinos...», Melchor de Berrio no aparece en estas negociaciones. 
Habsburgo estaba siendo sustituida por la continuidad con la idea última de sometimiento a través de la negociación y los servicios, que se transformaban en privilegios ${ }^{187}$. En palabras de Vincent, "Puede formularse la hipótesis de un primer periodo, de 1570 al comienzo de los años 1580, en el que los exiliados trataron de reconstruir mal que bien un tejido social a pesar de la hostilidad del entorno. Las élites, cuyo prestigio estaba intacto, jugaron un papel capital en este proceso. Pero el tiempo pasó, aquéllas perdieron mucho de su legitimidad, al tiempo que emergían otras familias que se habían adaptado bien, o mejor, a las nuevas condiciones de vida. Las estrategias individuales que suscitaron las iniciativas reales y la defensa de intereses particulares profundizaron divisiones que serían en adelante difícilmente superables" ${ }^{\prime 188}$.

Estos intentos por ganar posiciones reflejan unas aguas más profundas, en las que se mueven la extorsión, las necesidades continuas de ingreso de la monarquía y los vaivenes propios de la política sobre los moriscos. En otro plano, la capacidad de movilización económica, política y de influencias en el seno de la sociedad morisca y de la Corte tuvo como sostén más firme la actividad comercial de los hermanos Berrio y su disposición de una red de agentes en las principales plazas del reino, entre los cuales se contaban los hijos de Lorenzo de Berrio, como luego analizaremos.

Como ya señalamos, todo comenzó en 1577 en Ciudad Real ${ }^{189}$, donde los moriscos estaban muy alterados por el rumor de una vuelta, considerando el corregidor que los principales responsables del rumor habían sido "los dichos Lorençio de Berrio y Gaspar de Raya y que los mysmos testigos dizen que estos les avian persuadido a que consintiesen que ellos tratasen dello y aunque

187. M.F. FERnÁNDEZ ChaVES, op. cit.

188. B. VINCENT, «Los moriscos granadinos...», p. 179. Conclusiones con las que estamos plenamente de acuerdo, y que Vincent extrapola también al mal conocido servicio militar de los moriscos, que no analizamos aquí por no estar (que sepamos) directamente relacionado con los Berrio.

189. Aunque los diversos testigos retrotraen los tratos a febrero de aquel año, pudiéndose llegar hasta 1575, si damos crédito a la afirmación del morisco de Ciudad Real, Diego Bernabé Hernández, que indicaba que ya en aquel año coincidió en la Corte con María la Zagala, morisca notable de Padul, que había ofrecido la posibilidad de volver para él y otros moriscos. Si las acusaciones que veremos a continuación, vertidas contra el exprocurador de los moriscos y corregidor de Ciudad Real Jorge de Baeza eran ciertas, según las cuales el corregidor habría recaudado dinero de los moriscos para volver a Andalucía, ya en 1576 la idea de la vuelta y el pago de un servicio a cambio planeaban claramente en las mentes de los moriscos, AGS, CC, leg. 2179, interrogatorio de testigos. Lo cierto es que en 1576, último año del corregimiento de Baeza, éste se hallaba embarcado en una frenética actividad para recaudar las rentas reales y encabezadas de la ciudad -fundamentalmente alcabalas y tercias-, para lo que tuvo varios problemas, "yo he trabajado tanto quanto se puede encarecer y que toda la cibdad esta contra mi que me querian apedrear que no quisieran que llegaran las rentas a dos quentos quanto mas a cinco y mas como han llegado. Al fin si no me atajaran tan presto con quitarme la vara que yo tanto deseava los encaminara a que se encabezasen como se me envio a mandar...", cfr. AGS, Patronato Real, leg. 76, doc 25 y diversos documentos. Sobre Jorge de Baeza y su padre homónimo como procuradores y el cargo en sí, J. CASTILLO FERNÁNDEZ, op. cit., vol. II, pp. 199-200. 
trayrian provision de su magestad para que entre todos los moriscos del rreyno de granada rrepartiesen çierta cantidad de mrs. para ellos por su ocupaçion y trabajo...". Las promesas de los mercaderes consistían en "que su magestad les dava liçencia para bolverse a sus casas y que yvan de ordinario a tratar sobre ello desde Toledo a esa corte y dezian que sobre ello hablavan con su magestad a ynterçesion de don Alonso Vanegas que en esa corte rreside el qual les dezia que sobre ello avia hablado a su magestad y a otras personas prinçipales sus criados y que aviendo ofresçido a su magestad por esta liçençia çiento y quarenta myl ducados y que para su seguridad que ofreçian de sustentar seys galeras que anduviesen de ordinario en la costa de granada y mas dos myl soldados" ${ }^{\prime 190}$. El corregidor de Ciudad Real envió a su colega de Toledo una petición para que los encarcelase ${ }^{191}$. Según la declaración de testigos que participaron en la información hecha por el corregidor de la ciudad en mayo de aquel año, era bien conocido por los moriscos deportados en Ciudad Real y otros puntos que se estaba negociando la vuelta de los moriscos, precisada por algún testigo que era para los "leales". Tal era así, que el morisco de Ciudad Real Sebastián de Palma había escrito una carta a Lorenzo de Berrio para informarse del estado de las negociaciones. Éste había respondido a través del arriero morisco Andrés de Gumiel, indicándole que "andaban en buenos términos", aunque al no obtener respuesta del rey habían regresado a Toledo, con la promesa de Alonso de Granada Venegas por la que "presto bolberian a Granada y que su magestad les abia dicho que fianças le darian para que otra bez no se lebantarian contra su magestad...". Pero nada parece acordarse, aunque como señala Vincent varios notables de Toledo, entre los que debía contarse Berrio, escribieron a "los muy magníficos señores don Hernando Muley, Gerónimo Enríquez, Gaspar de Piedrahita, Alonso Hernández Camid y demás señores y amigos en Sevilla" para ponerse de acuerdo en el servicio ${ }^{192}$. Aparece aquí Sevilla como un punto importante en la red de solidaridad morisca, que cuenta entre sus más destacados miembros con mercaderes como Camid, o con un príncipe de sangre real de la categoría de Hernando Muley de Fez.

Tras el fracaso de la propuesta, parece que Lorenzo debió tener problemas en Toledo, porque en 1579, cuando volvió a plantearse el mismo ofrecimiento de un servicio a la monarquía, Lorenzo de Berrio era comisionado para el repartimiento como vecino de Sevilla, junto al también morisco Alonso Hernández Camid, y aunque en aquel servicio se proponía la vuelta de 2.000 casas de moriscos, nada se concretó ${ }^{193}$. Los factores fundamentales fueron la organización de una vuelta a Granada por los mercaderes, cuyos oficios de mediación

190. AGS, CC, leg. 2179. Citado por B. VINCENT, «Los moriscos granadinos...», p. 167. Vid también, M.F. FERnÁNDEZ CHAVES, op. cit.

191. AGS, CC, leg. 2179.

192. B. VINCENT, «Los moriscos granadinos...», p. 167.

193. Ibídem, pp. 167-168. 
política habían dado su fruto al obtener la supuesta autorización real, apareciendo el exprocurador de los moriscos, Jorge de Baeza, en el proceso; la no concreción del mismo suscita la inquietud y el cese de los intercambios económicos entre los moriscos, con la consiguiente preocupación de las autoridades por los perjuicios económicos y por la necesidad que se planteaba de averiguar si efectivamente se había cobrado un servicio (cosa que todos los testigos negaban), cuestiones muy difíciles de averiguar debido a que según el corregidor de Ciudad Real, "son tales estos moriscos que aunque les den çien tormentos no confesaran verdad". Lo cierto fue que el alcance de este rumor fue casi total, porque también en 1577 en la ciudad de Jaén se produjeron los mismos fenómenos, declarando los testigos conocer la existencia de unas negociaciones para la vuelta de los "leales" y que Lorenzo de Berrio y Gaspar de Raya estaban en ellas directamente implicados, teniendo supuestamente en su poder una cédula dada por Rodrigo Vázquez de Salazar, indicando un testigo que todo había partido de "don Alonso Vanegas veynte e quatro de granada avia hablado a Lorenço de Berrio vecino que fue de Granada que fuesen a Madrid a hablar con su magestd y que el dicho Lorenço de Berrio e otros dixeron que su magestad los habia mandado llamar"194.

Movilidad y una amplia red de contactos definen la actividad de los hermanos Berrio, contactos que según el testimonio anteriormente examinado, incluyen las conexiones de la aristocracia granadina en la Corte. Si bien no recuperaron sus bienes, "En revanche ils semblent bénéficier d'une liberté totale de mouvemente indispensable au succès de leurs affaires... avoir des contacts avec de nombreuses communautés d'exilés. Les autorités... voient en eux ces précieux intermediaires dont elle ont toujours besoin" ${ }^{195}$.

Como ya señalara Vincent, en el ofrecimiento del servicio participaron no sólo los exiliados, sino también los que habían quedado en Granada, al menos desde 1579. Esta alianza respondía a una solidaridad de grupo en la que los exiliados que proponían el servicio quedaban asociados a aquellos que la propia monarquía había premiado con la estancia en Granada por su fidelidad. Toda una operación de "enderezamiento" de la memoria en la que precisamente los Berrio se habían contado entre los sospechosos en la rebelión de 1568, y en la que se hallaban también otros señalados habitantes del reino, muchos de ellos mercaderes ricos como Lorenzo Hernández el Chapiz, Hernán López el Ferí, Gaspar de Raya, y otros pertenecientes a la aristocracia colaboracionista como los Abenajara ${ }^{196}$. Con la última expulsión de 1584 las posibilidades del retorno a Granada se volvían más escasas, aunque los moriscos ganaron un gran reconocimiento por parte de la monarquía al establecerse por vía de provisión la primera diferenciación entre moriscos exiliados "buenos", o

194. AGS, CC, leg. 2179.

195. B. VINCENT, «Les frères Berrio...», p. 926.

196. M.F. Fernández ChaVes, op. cit. 
colaboracionistas durante la guerra, y los "malos", perpetradores del crimen de lesa majestad por el que habían pagado los de "paces" injustamente, y por tanto la capacidad de estos moriscos para conseguir un representante por cuatro meses que defendiera su posición y relatar los agravios que sufrieran ${ }^{197}$. Fue esta toda una conquista por cuanto la monarquía reconocía por primera vez esta división entre leales y traidores, tan cara al planteamiento del servicio.

Pese al fracaso de las proposiciones de un acuerdo "por bia de contrato de lyçençia" como se expresaba en 1577 y después en 1579, los moriscos no dejaron de emplearse a fondo en restaurar sus maltrechas posiciones y en establecer nuevos vínculos y alianzas sobre un tablero de relaciones sociales y políticas completamente modificado. En esta década el ascendiente de los miembros más esclarecidos de la comunidad morisca tuvo que jugar un papel importante, habida cuenta de que puede considerarse que el principal objetivo de estas élites y de la mayor parte de los deportados era volver al Reino de Granada. A favor de esta idea juegan varias razones. Una parte de la aristocracia del reino había quedado en suelo granadino, merced a su colaboración con la Corona, aunque en muchos casos con mermados patrimonios ${ }^{198}$. Otra había sido expulsada, o había conocido el castigo ejemplar ${ }^{199}$, y a la larga sólo su capacidad para poder continuar siendo considerados como los líderes naturales de la comunidad morisca les posibilitó mantener dicho estatus. Fueron precisamente las familias ricas y bien consideradas las que acabarían representando en el exilio una dura competencia para la aristocracia, dado que disponían de mayores recursos y de sólidas redes de agentes en el territorio castellano. Todos programaron como objetivo político para los naturales del reino de Granada la vuelta a la tierra de sus ancestros, con desigual éxito según los momentos. Fue esta una nueva vía que se adaptaba a las exigencias de la Corona, que había dejado suspendidos la mayor parte de los privilegios forjados en la conquista y en los sucesivos aplazamientos de la aplicación de las medidas de aculturación desde antes, incluso, de las medidas de la Capilla Real de Granada de $1526^{200}$.

Parece que el fracaso de los planes de los que podríamos llamar "mercaderes" en la segunda mitad de los años 70 dejó paso a un intento liderado desde la aristocracia. Es el caso de la rebelión frustrada de Fernando Muley en Sevilla

197. A. García LóPEZ, «Conflictividad y conciencia. La aplicación de justicia a la minoría morisca en el Reino de Castilla», en A. MEsTre SANCHís y E. GIMÉNEZ LópeZ (coords.), Disidencias y exilios en la España Moderna, Actas de la IV Reunión Científica de la Asociación Española de Historia Moderna, Alicante, Caja de Ahorros del Mediterráneo, Universidad de Alicante, 1997, vol. II, pp. 455-468, concretamente, p. 461. La provisión fue dada en Madrid, 24-V-1584.

198. B. VINCENT, «Los moriscos que permanecieron...», pp. 267-286. R.M. PÉrez GARCía, op. cit., pp. 35-50.

199. Como muestra el caso de los Valor, estudiado por F.J. CANO HILA, «Apuntes históricos sobre el linaje de los Córdoba y Válor», Farua. Revista del Centro Virgitano de Estudios Históricos, 12, 2009, pp. 229-276.

200. R.M. Pérez García, op. cit., pp. 38-40; y R.M. Pérez García y M.F. Fernández Chaves, op. cit. 
en 1580, que ha llamado poderosamente la atención de la historiografía. Muley había estado realizando una serie de contactos entre 1579 y 1580 con diversos moriscos en Córdoba y Écija para conseguir un levantamiento general. Por su confesión sabemos que no halló gente "fiable" en ambas ciudades, pues en Écija "busco moriscos con quien poder tratar de lo susodicho e hallo que avia pocos con quien lo poder tratar... hallo moriscos naturales de Ronda que avian ydo desta ciudad con pasaporte e por ser gente de poca suerte e de quien no se podia hazer caudal no trato con ellos ninguna cosa..." y aún peor era la imagen de Córdoba donde "vido que los moriscos que avia en la dicha cibdad hera gente rota e ruyn porque la gente buena la avian llevado a Pastrana"201, donde precisamente los "mercaderes" tenían una sólida implantación, merced a la política de Ruy Gómez de Silva, príncipe de Éboli, encontrándose entre los más importantes miembros de esta comunidad a Hernán López el Ferí202.

Según un acusado, "al dicho don Fernando alçavan por capitan mayor porque es principal de buena sangre de Granada..." y esta categoría ya había sido reconocida por las propias autoridades, dado que D. Fernando trataba los asuntos concernientes a su comunidad con el Asistente ${ }^{203}$, cosa que pone en cuestión el sistema de organización diseñado por la Corona para administrar a los moriscos, reduciendo a la inutilidad la figura del supertintendente de los $\operatorname{moriscos}^{204}$. Los moriscos acaudillados por Muley diseñaron una revuelta que tenía por objeto aprovechar la marcha de muchos hombres para el ejército que se aprestaba para entrar en Portugal, y después de realizar el mayor daño posible, la intención era alcanzar las sierras de Ronda para volver al Reino de Granada. El modelo era el de la rebelión de once años antes: búsqueda de un

201. B. VINCENT, «Les rumeurs de Séville», en B. BENNASSAR PÉRILLIER et al., Vivir el siglo de oro. Poder, cultura e historia enel época moderna. Estudios en homenaje al profesor Ángel Rodríguez Sánchez, Salamanca, Universidad de Salamanca, 2003, pp. 165-178. M. BoEGLIN, «Entre la resistencia a la política de asimilación y la fabulación: el "levantamiento" de los moriscos andaluces de 1580», Historia, Instituciones, Documentos, 34, 2007, pp. 29-55. M.F. FERNÁNDEZ CHAVES y R.M. Pérez García, En los márgenes de la Ciudad de Dios... A.L. Cortés PeÑA, «Una consecuencia del exilio: los moriscos granadinos en Sevilla», en E. BelEnguer CEBriÁ (ed.), Felipe II y el Mediterráneo, vol. II, Madrid, Sociedad Estatal para la Conmemoración de los Centenarios de Felipe II y Carlos V, 1999, pp. 537-553.

202. Quien precisamente era uno de los cuatro mercaderes más importantes de la villa junto a Diego Hernández Chapiz, ¿hijo? de Lorenzo Hernández Chapiz, C. Álvarez DE MORALES, «Lorenzo el Chapiz y el “Negocio General” de 1559», Qurtuba, 1, 1996, pp. 11-38. Cf. A. GARCía López, Señores, seda y marginados. La comunidad morisca en Pastrana, Bornova, Consejería de Cultura, Turismo y Artesanía de la Junta de Comunidades de Castilla-La Mancha, 2009, pp. 270-277.

203. B. VINCENT, «Los moriscos granadinos...», p. 166; su casa se denominaba "aduana" de la comunidad. Cfr. AGS, Consejo Real, leg. 257, expte. 4.

204. La adminstración de las comunidades moriscas tuvo como marco una pragmática dada en Toledo en 1572, que ha sido analizada por F.J. MORENO DíAZ DEL CAMPO, Los moriscos de la Mancha. Sociedad, economía y modos de vida de una minoría en la Castilla Moderna, Madrid, CSIC, 2009, pp. 281-286. No obstante, detectamos su actividad después de la frustrada rebelión de 1580, sobre todo en momentos de cambio como fueron las negociaciones firmes sobre el servicio a partir de 1589, M.F. Fernández Chaves y R.M. Pérez García, En los márgenes de la Ciudad de Dios..., p. 330. 
príncipe de la sangre para nuclear las lealtades de la rebelión, proclamación de la "secta de Mahoma", acumulación de armas, espera de un día señalado para los cristianos (la fiesta de San Pedro), produciendo, en definitiva, una catarsis violenta de la situación. Es conocido el fracaso de este proyecto antes de que se realizara, y cómo la justicia actuó expeditivamente contra los implicados en este asunto. En todo él no puede olvidarse que Fernando Muley de Fez tenía una tienda de especiería, negocio al que se dedicaban muchos moriscos (entre ellos los Berrio) y que precisamente Lorenzo de Berrio y el Muley convivieron en Sevilla al menos desde 1579.

La amplitud geográfica de sus contactos (en este caso Sevilla, Écija, Córdoba) y la vuelta al Reino de Granada como leitmotiv absoluto de la voluntad última de los moriscos son dos factores que ya habían jugado su papel en las proposiciones del servicio hechas en 1577 y en 1579, y tampoco tendrían efecto en 1580 .

\section{LA “RED BERRIO” Y LOS PROBLEMAS DE LA FAMILIA}

Ya sabemos que Lorenzo se casó en los años cincuenta con Elena Sánchez Zinetia y tuvo al menos cuatro hijos: María, Alonso, Juan y Luis. En su destierro contaba además con la constante ayuda de su hermano, Melchor, que parece residir gran parte del tiempo en Sevilla. El exilio les obligó a amplificar conforme a la dispersión geográfica del colectivo sus vínculos comerciales y de apoyo político, "colocando" Lorenzo a sus hijos y hermano en distintos puntos clave anejos a sus intereses.

El año de 1585 constituye un punto de inflexión en la historia del exilio morisco, puesto que se ordenó desde Madrid centralizar en el Consejo de Población todos los procesos abiertos en tribunales locales y regionales para justificar su condición de cristianos viejos, "diziendo ser descendientes de tales Christianos viejos, como por haverse convertido sus passados a nuestra sancta fee Catholica, antes de la conversion general o venido de Affrica a recevirla". Se daban sesenta días para enviar toda la documentación a dicho Consejo bajo la supervisión del secretario de la Cámara, Juan Vázquez de Salazar, quedando revocadas las ejecutorias que no se presentasen ${ }^{205}$. La reclamación de los moriscos giraba normalmente en torno al derecho a poseer armas, signo de estatus de cristiano viejo, forzando muchas veces la apertura de causa portando las armas, para que fuesen detenidos y realizar las probanzas.

205. Monzón, 3-IX-1585. Su contenido y el significado de sus disposiciones fueron analizados por M. ${ }^{a}$ J. GARCía GÓMEZ, «La provisión real de 3 de sepiembre de 1585: los procesos sobre la condición social de los moriscos de la corona de Castilla», en La Administración de Justicia en la Historia de España: Actas de las III Jornadas de Castilla-La Mancha sobre investigación en Archivos, Guadalajara, Junta de Comunidades de Castilla-La Mancha, 1999, t. I, pp. 169-191. 
Esta provisión motivó la reacción inmediata de los Berrio. Así, el mismo mes de octubre de 1585 Melchor de Berrio daba un poder en Sevilla al también morisco Jerónimo de Aguilar ${ }^{206}$ para que pudiera comparecer en el Consejo de Población de Madrid, especialmente ante el secretario Juan Vázquez de Salazar y pudiera "presentar qualesquier provanças e ynformaçiones e autos y sentençias y previlegios y çedulas rreales y otros recaudos que en mi fabor tenga y pedirse ayan presentado y que se declare yo no ser de las personas contra quien en la dicha provision que ansi esta publicada y todo lo demas que a mi derecho y justiçia y en mi fabor convenga y que las dichas çedulas y previlegios y autos, sentençias y otros rrecuados en mi nombre presenta me sean guardadas y cumplidas y mandadas guardar e cumplir" ${ }^{207}$. Por tanto Melchor de Berrio no demandaba que se le reconociese como cristiano viejo por ser morisco, sino que reclamaba aquella condición por el hecho de que no se consideraba uno de los nuevos convertidos. Esta actuación debió coordinarse con la de su hermano y sobrinos, puesto que tenemos constancia del asiento en los libros de cédulas de la Cámara del reconocimiento como cristianos viejos de Lorenzo y Melchor, según el corregidor de Toledo, haciéndose extensivo por descendencia a un hijo de Lorenzo, Juan Pérez de Berrio ${ }^{208}$. M. Josefa García destaca la existencia de sendas requisitorias para reconocer su condición cristiano vieja relativas a Lorenzo y Melchor de Berrio, "mercaderes adinerados de dicha ciudad de Toledo que habían liderado una actuación corporativa de los moriscos del reino de Granada avecindados en las principales ciudades castellanas ante el rey y su Consejo ofreciendo una suma de dinero a cambio de la autorización de su regreso al reino de Granada" ${ }^{209}$. El mismo problema tuvieron los moriscos más importantes de la villa de Pastrana, mercaderes de sedas, a quienes se les confiscaron las armas de las que disponían antes de cumplirse el plazo de sesenta días dado para presentar probanzas de cristiano viejo, por lo que protestó el morisco Luis de Mendoza, que hablaba por el resto de moriscos principales de la villa ${ }^{210}$. Desde la villa se informaba que los moriscos

206. Cuyo hermano Ambrosio había sido amparado por Melchor como fiador en su pleito como cristiano viejo, pretendiendo descender ambos hermanos de Hamete Uleylas. Cfr. M.F. FERNÁNDEZ Chaves y R.M. Pérez GARCíA, «La familia morisca de los Oleylas», en prensa.

207. AHPSe, PNS, leg. 168, f. 479r y ss, Sevilla, 19-X-1585.

208. AGS, CC, libro de cédulas 263, f. 11v, 24v y 25v, fechadas en Madrid el 22-XI, el 3-XII y el 4-XII1585. Sólo en aquel año se presentaron 401 causas judiciales, contándose entre octubre y diciembre 87 ejecutorias, 56 procesos, 21 requisitorias, 4 provisiones, 4 cédulas reales y otros testimonios, M. J. J. GARCía GÓMEZ, op. cit., p. 187.

209. M. ${ }^{a}$ J. GARCía GÓMEZ, op. cit., p. 188.

210. AGS, CC, leg. 2192, 5-XII-1585, anotado por Salazar en 16-I-1586 "juntese con lo demas". Estos moriscos eran "Alvaro y Jeronimo Hermez y Melchor Lopez y Miguel Rodriguez y Damian Hernandez y Diego de Mendoza cantarero y Sebastian Lopez de Napoles y su hermano y Melchor de Luxan y Alonso de Ximenez, Alvaro de Soto y Jeronimo de Salazar, Sebastian Lopez de Castilla Miguel de Rueda, Luis de Valdivia y Gaspar de Arraya (sic) y Heronimo Romero y otros que parescen culpados". 
allí avecindados habían conseguido ejecutorias para llevar armas y que se reconociera su condición de cristianos viejos, insistiendo en llevar armas para ser prendidos e iniciar un proceso judicial. Y aunque se señalaba que había muchos moriscos que habían inmigrado a la villa sin pasaporte y que conseguían ejecutorias, desterrarlos sería antieconómico ${ }^{211}$.

Estas dificultades añadidas evidencian la poca disposición de las autoridades a conceder facilidades a los moriscos y menos aún en el caso de la vuelta a Granada. En efecto, al año siguiente Melchor de Berrio necesitaba de los oficios de un berberisco, Diego Márquez, para que como procurador pudiera comparecer ante los justicias de Granada y presentase un requerimiento para prender a uno de sus deudores y lo enviaran a la cárcel de Sevilla o en su defecto embargasen sus bienes ${ }^{212}$. Pues el Consejo de Población había reconocido la condición de cristianos viejos de los litigantes aunque "se restringían los efectos de los pronunciamientos judiciales en los que se negaba la condición de moriscos de los demandantes reconociéndoles todos los derechos inherentes a ello -posesión de armas, libertad de movimientos etc.- excluyendo la libertad de volver al reino de Granada" ${ }^{213}$. Diego Márquez actuaba como agente de Melchor, apareciendo también como fiador en la venta que hacía de una esclava ese mismo año de $1586^{214}$.

Mientras Lorenzo parece que tiene a su cargo los negocios en Madrid y en Castilla, Melchor aparece más vinculado a Andalucía, estando muy presente en la ciudad de Sevilla. En la céntrica collación de Santa Catalina de Sevilla y declarándose como vecino de la misma, vivía también el morisco Alonso Hernández Camit (o Camino como firma en Sevilla), que aparece como delegado encargado del servicio morisco en las propuestas hechas a la monarquía en 1577, junto a Lorenzo de Berrio por Sevilla, Córdoba y Extremadura en $1579^{215}$, y en la de $1589^{216}$. Natural de Granada, en 1564 aparece en los protocolos notariales de la ciudad del Darro como Alonso Hernández "el Camit"217. En Sevilla, Camino tenía también el perfil de mercader: importaba, como los moris-

211. "Muchos de los quales son neçesarios para el trato de la seda y otros tratos y granjerias de que resulta probecho a las alcabalas... como mas largamente di dello relazion el año pasado de ochenta y tres en el consejo... los quales estan por alistar y ellos y sus hijos podran dezir que pueden traer armas y salir sin licencia...", AHN, Consejos, leg. 53305.

212. AHPSe, PNS, leg. 170, f. 538r-v, 27-VI-1586. El deudor se llamaba Luis de Contreras.

213. M. J. J. GARcía GómEZ, op. cit., p. 190. Aunque el acuerdo del Consejo de Población que publica la autora databa de 14-III-1588.

214. AHPSe, PNS, leg. 1594, f. 705v-r.

215. B. VINCENT, «Los moriscos granadinos...», pp. 167-168.

216. AGS, CC, leg. 2189.

217. AHPrGr, G-140, índice del legajo, referencia a una obligación contra Alonso el Serrax. 
cos de Pastrana ${ }^{218}$, sedas de Murcia ${ }^{219}$, y tenía relaciones con familias cristiano viejas de Extremadura, de quienes era apoderado para cobrar sus rentas situadas en la alcabala de Sevilla ${ }^{220}$; para todos estos menesteres trabaja con su socio Diego Sánchez, de quien sabemos que también era morisco, puesto que aparece como delegado precisamente para el partido de Badajoz, cuando se perfilaron los delegados de cada zona a recaudar en la reedición del servicio del año $1597^{221}$. Aunque por ahora no tenemos más información sobre él, parece claro que tuvo que trabajar en sintonía con ambos hermanos.

A priori no parece que Melchor de Berrio se dedicase al negocio de la seda, aunque como otros moriscos sevillanos, también estaría implicado en el negocio del abastecimiento del carbón a la ciudad; de esta forma, sabemos que en 1586 pagó 1.402 ducados por mil carretadas de leña sacada del término de Gibraleón ${ }^{222}$, siendo su fiador Alonso Sánchez, hermano del abogado de la Audiencia Juan Sánchez ${ }^{223}$. Parece que no había dejado el tráfico de mulas, puesto que ese mismo año vendía una a un atahonero de Olivares, y perdonaba a un trabajador que le había robado otro macho que había acabado vendiendo a otro atahonero en Osuna, gracias a que el comprador al conocer el origen del animal lo había devuelto sin $\operatorname{costes}^{224}$. Vendió asimismo la esclava a la que aludimos antes en 1586 y otra más en 1588, ganando 150 ducados con ambas operaciones ${ }^{225}$.

218. A. GARcía López, Señores, seda y..., pp. 265-270. Al estar controlados sus movimientos Hernández Camino y su socio recurrirían a un mercader cristiano viejo, como también hacían los moriscos de Pastrana.

219. Junto con Diego Sánchez, vecino en la collación de Santiago el Viejo, daba poder en 1587 al jiennense Gonzalo Tercero para que cobrase del mercader de sedas sevillano Gaspar Carballo 7.303 reales de plata que les adeudaba, declarando que dejaban de pagarle 1.203 reales de resto de 8.326 "reales y medio de çiento e quarenta e ocho libras e onze onzas de seda joyante en maço de murcia que le compramos horros de todos derechos que nosotros auemos pagado", AHPSe, PNS, leg. 12511, f. 139v.

220. Concretamente del trujillano Jerónimo de Loaysa y sus hermanos, de nuevo con Diego Sánchez, 98.765 mrs. de un juro sobre las alcabalas de Sevilla y un resto de la misma renta por valor de 26.625 mrs., cobrados de Pedro de Mendoza, AHPSe, PNS, leg. 12510, f. 333r-v y 370r-v, 2-XI-1587. Camino vuelve a aparecer en 1588 cobrando para Loaysa 98 reales y 875 mrs. librados en el banco de Diego de Albuquerque, AHPSe, PNS, leg. 12512, f. 295r.

221. B. VINCENT, «Los moriscos granadinos...», p. 173.

222. AHPSe, PNS, leg. 172, f. 5r-6r. El vecino de San Lorenzo Alonso Sánchez se obligaba a recoger la leña en el campo del Andévalo que entraba en el término de Gibraléon.

223. AHPSe, PNS, leg. 171, f. 906v-907v, siendo pagados los 1.402 ducados así: 100 ducados el 1 de enero de 1587, otros 300 a fin de abril, 300 ducados a fin de agosto y otros 300 a fin de diciembre, todo en 1587, quedando la paga de los 402 ducados restantes para fin de abril de 1588 .

224. AHPSe, PNS, leg. 172, f. 7r-v, f. 214r, y f. 664r-v. El atahonero de Olivares Francisco de Aguilar compraba por 14 ducados el macho "mediano cerrado castaño", y un par de meses después recuperaba otro "macho mio castaño labrado de las manos con un piquete en la oreja izquierda" robado por Francisco Martín, también "moledor de atahona", del que solicitaba su liberación de la cárcel de Osuna para "descargo de mi conciencia" al haberlo devuelto el también atahonero del Arahal Pedro Fernández.

225. Fueron la esclava mulata vendida a la trianera Margarita de Padilla, y otra mulata hija de "morisco berberisco" que compró también un cristiano viejo, Juan López de León; la venta de 1588 en AHPSe, PNS, leg. 1594, f. 705v-706r, leg. 175, f. 269r-v. 
En 1587, Melchor daba un poder a su hermano Lorenzo para que pudiera en su nombre llevar adelante todos los pleitos y cobrar todas las deudas que le estuvieran pendientes de pago, cosa que indica que Lorenzo disponía de la red más compleja para garantizar el cobro de deudas ${ }^{226}$. Estos atahoneros con los que trabajaba Melchor de Berrio, y el papel que en el abasto del carbón tiene este morisco, nos indica que como otros correligionarios, se dedicaba a actividades relativas al abastecimiento básico de la ciudad, como el pan y el carbón ${ }^{227}$. No por casualidad se decía de los moriscos en la Sevilla de 1588 que tenían "grandes riqueças, aunque no lo muestran exteriormente por ser como son generalmente mezquinos, y el real que una bez entra en su poder no saven trocarle, y en esta Sevilla y Andalucia compran y venden cossas de comer y amasan y venden la mayor parte del pan que se come que lo uno y lo otro es el trato que mas enriqueçe" 228 .

En 1591 no encontramos a Melchor de Berrio, pero sí a su sobrino Alonso Pérez de Berrio, quien parece haber estado de paso, puesto que traspasó los ocho meses que le quedaban de arrendamiento de unas casas en la plaza de la Feria a un panadero por cuatro ducados al $\operatorname{mes}^{229}$. No sería hasta la puesta en marcha del servicio morisco, cuando hallamos de nuevo en Osuna en febrero de 1592 a Melchor como comisario del rey para el reparto del servicio de los 200.000 ducados ${ }^{230}$, que como veremos se había comenzado a tratar más en serio en 1589. A partir de aquel momento las noticias escasean, siendo la última que hemos podido recoger correspondiente a 1595, año en el que era cesionario de un tal Martín de Ojeda, por quien cobraba 1.000 reales de plata a Juan Alonso de Negrón. Se había mudado a la collación de San Ildefonso, mucho más céntrica y aristocrática que la de Omnium Sanctorum ${ }^{231}$.

Alonso Pérez de Berrio, que ya hemos visto desplazado a Sevilla en 1591, parece haber seguido la carrera de su padre y su tío. Su presencia en Sevilla que acabamos de comentar es circunstancial, puesto que su ámbito de actuación estaba en la ciudad de Ávila, donde se había afincado siguiendo los negocios de su padre ${ }^{232}$; sabemos que en 1588 se declaraba mercader, por lo que podemos

226. AHPSe, PNS, leg. 172, f. 699r.

227. M.F. Fernández Chaves y R.M. Pérez García, En los márgenes de la Ciudad de Dios..., pp. 266 y 409.

228. Informe de D. Alonso Gutiérrez, Sevilla, 6-XI-1588, publicado por P. BORONAT Y BARRACHINA, Los moriscos españoles y su expulsión, Granada, Universidad de Granada, 1992, t. I, pp. 634638, y aquí, p. 635.

229. AHPSe, PNS, leg. 184, f. 1007r-v. Alonso vivía en los "solares de San Clemente", una nueva zona recientemente urbanizada por las monjas del convento homónimo, situada al extremo norte de la Alameda.

230. AGS, CC, leg. 2199.

231. AHPSe, leg. 9286, f. 182r-v, recibidos en cinco esportillas de menudos por valor de 100 reales cada una y el resto pagado en reales de plata. Sevilla, 10-VII-1595.

232. Aparece en el censo creado por la Inquisición en 1594 como mercader de sedas granadino (sin el "Berrio") bajo el nombre de Alonso Pérez, casado con Juana Pérez, y sabe firmar. S. de TAPIA SÁNCHEZ, La comunidad morisca de Ávila, Salamanca, Universidad de Salamanca, 1991, p. 487. 
presumir que continuaba comerciando con seda y otros productos, aprovechando sus contactos en el reino granadino y Toledo como gran capital manufacturera, que permitían a los Berrio continuar con su negocio de redistribución en el mercado castellano.

Pero en 1588 Alonso Perez de Berrio tuvo graves problemas con el concejo de Ávila, abriéndosele un proceso muy duro que haría palidecer los avatares que sus hermanos tuvieron con la Inquisición ${ }^{233}$. Así, el 19 de enero de 1588 Lorenzo de Berrio se querelló "como padre legitimo administrador" en nombre de su hijo Álonso Pérez de Berrio, contra el corregidor de la ciudad, Alonso de Cárcamo y el Dr. Alonso de Frías, corregidor y alcalde mayor de Avila respectivamente, pues Alonso había sido acusado de morisco y por tanto de contravenir las reales disposiciones al llevar espada, resistiéndose al alguacil de la justicia de Ávila y consiguiendo partir la vara que portaba.

Alonso Pérez de Berrio recordaba en la Chancillería de Valladolid que ya había ganado una sentencia a su favor en los tribunales abulenses para condenar la actuación del corregidor "por aver sido tan exorbitantemente hecho estaba dado por nynguno... haviendose restituydo al dicho Alonso Perez de Berrio en su buena honrra y fama de la forma y manera que estava antes...". Padre e hijo se quejaban puesto que los dos oficiales le habían abierto un proceso con injurias y "por pasión... por ocasión que havia hecho cierta resistencia al dicho alguacil y propuesto el temor de Dios" y, llevado preso, en sólo una hora fue condenado a doscientos azotes y a pena de seis años de galeras, "y luego había ejecutado la sentencia publicamente por las calles de dicha ciudad", siendo llevado a Toledo para alistarlo con los demás galeotes que allí se reunían. Para los Berrio "lo peor" era que no le habían dado la más mínima ocasión de defenderse. La justicia ordenó el arresto del corregidor y de su teniente y su encarcelamiento en la cárcel de la Chancillería. Se ordenó confiscar sus bienes y se comprobó en la pesquisa que se habían extralimitado en su actuación. No pensaba así el corregidor Cárcamo, que se defendía argumentando que la celeridad del castigo respondía a "la calidad del negocio, por apaciguar mucho escandalo que avia avido". En el concejo se decidió que el desacato debía ser castigado de forma expeditiva, y a ello contribuía "la calidad de la persona... por ser como hera morisco y persona acostumbrada a cometer otros muchos delitos" ${ }^{234}$. Aquí radicaba la base del problema, porque Alonso Pérez de Berrio había presentado también testigos que defendiesen su condición de hidalguía y su origen cristiano viejo, sabiéndose por una declaración suya en otro pleito que "hera de generazion de moriscos". A mayor abundamiento, el joven Alonso ya había sido encontrado culpable de la muerte de un hombre

233. Para todo lo que sigue, Archivo de la Real Chancillería de Valladolid, Registro de Ejecutorias, caja 1604, expte. 41.

234. Por supuesto, los testigos que habían declarado a favor de Alonso eran todos moriscos y no se habían hallado en el momento de la lucha, f. 8v. 
hacía tiempo, y después de habérsele dado tormento se le había condenado en 300 ducados y una pena de destierro, por lo que se justificaba su fama de hombre "inquieto y reboltosso". Los Berrio seguían sosteniendo que todo había sido por odio y nada tenía fundamento de justicia, sentenciando la Chancillería de Valladolid el 6 de octubre de 1588 que el corregidor Cárcamo debería pagar 200 ducados a Alonso Pérez de Berrio, y 300.000 mrs. para la Cámara, y otros 10.000 mrs. para la misma institución Alonso de Frías. Los Berrio se quejaron, pues consideraron que la sentencia se quedaba corta, pidiendo una pena de 3.000 ducados en razón de que no había habido causa judicial abierta en forma, dado que sencillamente Alonso Pérez de Berrio era cristiano viejo, y justamente por ello nunca había tenido ningún problema. Tras esta apelación vino la de Cárcamo, pero la sentencia quedó como estaba el 15 de diciembre de 1588, siendo condenados Cárcamo y Frías en las costas del juicio, elevadas a 57.588 mrs. el 18 de enero de 1589.

En Andalucía, concretamente en la ciudad de Baeza, residían también otros dos hijos de Lorenzo de Berrio, cuya proximidad al Reino de Granada la dotaba de un singular interés; además de disponer de un importante tejido industrial y una feria de ganado era sede de la Universidad creada por los conversos Rodrigo López y Juan de Avila, cuyo carácter abierto a los cristianos nuevos ${ }^{235}$ posiblemente favoreciese que Luis Pérez de Berrio obtuviese el título de Bachiller en Artes ${ }^{236}$.

Como muestra de la vulnerabilidad de los Berrio, la segunda mitad de la década de los ochenta viene a ser quizá su momento más complicado, aunque los hiperbólicamente mayores agobios de la monarquía vendrían paradójicamente en su ayuda. La mancha de la sospecha, que el tiempo y los oficios de Lorenzo de Berrio iban alejando de la familia, volvió a saltar de nuevo esta vez en la persona de sus hijos, quienes tendrían problemas con la Inquisición y otras autoridades. En 1586 la Inquisición de Córdoba procesó a Juan Pérez de Berrio, también morador en Baeza, por haber encubierto a su hermano, Luis Pérez de Berrio, quien estaba realizando una copia y traducción del Corán en su casa. Su resistencia frente a los alguaciles de la justicia dio tiempo a Luis para escapar. Aunque procesado, Juan venció el tormento y acabó siendo absuelto $^{237}$. Según otro testimonio ${ }^{238}$, Luis Pérez de Berrio había sido hallado co-

235. A. Huerga, Historia de los alumbrados. Los alumbrados de la Alta Andalucía (1575-1590), Madrid, Fundación Universitaria Española, 1986, vol. II, pp. 97-126.

236. Habría que buscarlo en los libros de matrícula de la antigua Universidad, a cuya existencia se refiere F. ESCOLANO, «Documentos y noticias de la antigua Universidad de Baeza», Hispania, 5, 1945, pp. 38-71. De todos modos un documento de 1595 nos informa que hacia 1588 ó 1589 estaba en Baeza estudiando Artes en ella (AGS: CC, libro de cédulas 264, f. 54. 18-X-1595).

237. R. GRACIA BoIX, op. cit., p. 210. Por el mismo delito fueron encausados y luego absueltos Damián Hernández y Beatriz de Cárdenas, mujer de Miguel Fernández, todos vecinos de Baeza.

238. Recogido por L. Coronas TejadA, La Inquisición en Jaén, Jaén, Diputación Provincial de Jaén, 1991, pp. 103-104. 
piando el Corán "por la justicia leyendo el libro del alcorán a mucha cantidad de moriscos en unos sótanos, o cuevas, y aunque estos fueron presos y sentenciados por el Sancto Oficio de la Inquisición... no pudo ser habido...", demandando el rey que se reuniese toda la información pertinente y se remitiese a Vázquez de Salazar ${ }^{239}$. Luis había escapado a Osuna, escondiéndose en casa de otro morisco, Lázaro de Valdivia, hasta que su padre Lorenzo de Berrio lo recogió sin que el sastre Valdivia supiera adónde fueron. Aunque Valdivia se defendió diciendo que lo acogía pensando que huía de la justicia secular "por una puñalada que habia dado" fue condenado a salir en el auto de fe cordobés de 1585, abjurar de levi y recibir cien azotes ${ }^{240}$. Finalmente, Luis Pérez de Berrio acabó apareciendo ${ }^{241}$, y después de haber superado el correspondiente tormento, fue condenado a salir en forma de penitente en el auto de fe de 1590 en Córdoba y a abjurar de vehementi, además de tener prohibida la entrada en el Reino de Granada y la permanencia a menos de quince leguas de la costa, y al destierro del territorio del distrito inquisitorial. Según el testimonio inquisitorial, después de escapar de su casa en Baeza "en cueros", consiguió marcharse "a Roma, donde se presentó en la General Inquisición, que dorando sus culpas y delitos como le pareció, ganó un Breve de absolución, con el cual se presentó en este Santo Oficio, y visto que traía clausula, que la absolución le aprovechase con que hubiese confesado enteramente la verdad y con que la causa no estuviese prevenida en el Santo Oficio de España" ${ }^{242}$. El caso es interesantísimo, en cuanto muestra cómo Luis Pérez de Berrio conocía el Corán y la lengua árabe, aunque se justificara contradiciéndose al indicar que no lo entendía ni sabía que era el Corán, haciéndolo "para poder servir de intérprete como otros lo hacían y ganaban con ello de comer y honra" ${ }^{243}$.

Así pues, toda la familia había sido sospechosa de una dudosa fidelidad a la Corona y de una deficiente cristianización: Lorenzo y Melchor en el primer caso y Melchor, Luis y Juan en el segundo, siendo Alonso encausado por la justicia civil abulense. Pero el ascendiente de Lorenzo de Berrio sería demasiado fuerte como para que estos contratiempos no fueran superados a partir de 1589, protegiendo a su hijo Alonso en 1589 y desplegando una red de contactos tan amplia que pudo amparar a su hijo Luis en el viaje y residencia en Roma, hecho que por sí solo nos indica la importancia del personaje y la magnitud de su capital relacional y financiero.

239. AGS, CC, libro de cédulas 264, f. 54, 18-X-1595.

240. R. GRACIA BoIX, op. cit., p. 194.

241. En carta de 15 de junio de 1587 el inquisidor licenciado Montoya escribe desde Córdoba al Consejo diciendo que "el bachiller Luis de Berrio" está preso en las cárceles secretas y su proceso "votado y está en el Consejo" (A. HuERGA, Historia de los alumbrados, vol. II, pp. 614-615, remitiendo a AHN, Inquisición, leg. 1856/1, s.f.).

242. R. Gracia Boix, op. cit., p. 241. Presentan el caso de manera resumida, M. García-Arenal y F. RODRíGUez MEDIANO, op. cit., p. 64.

243. R. GRACIA BoIX, op. cit., p. 241. 


\section{LA CONCRECIÓN DEL SERVICIO Y SUS DIFICULTADES: 1589}

En febrero de 1589, las Cortes de Castilla emitieron su voto consultivo aprobando el primer servicio de millones de la historia de la monarquía hispánica, que no se concretaría hasta la primavera de 1590. El mismo mes los moriscos habían estado tanteando de nuevo la voluntad de la Corona para aceptar un servicio, y sobre ello consideraba Felipe II que no había nada que perder, indicando "Es muy bien mandarles lo que pareçe sin desesperarlos del todo del negoçio que aunque no se aya de hazer, puede convenir para otras cosas que esten pendientes del, y al don Alonso escrivireis vos Juan Vazquez conforme a lo que parece", resolviendo el rey que acudieran a la Corte dos personas para iniciar las conversaciones ${ }^{244}$.

Una de estas personas tuvo que ser Lorenzo de Berrio. Él mismo lo indica en un memorial fechado en abril de 1589, donde recordaba su petición "en nombre de los naturales del reyno de Granada que an sido y son leales dize que otras bezes a suplicado a vuestra magestad les haga merced de mandarles dar licencia para bolber al dicho reyno como vuestra magestad sea servido en ello y agora se a tornado a mober hesta platica sobre hello a ablado con el Presidente de hacienda. Supplica a Vuestra Magestad sea servido e mandar delatar su boluntad y siendo hesta mande señalar ministro con quien pueda tratar los medios que mas convengan al serbicio de Vuestra Magestad porque lo haran confome la obligacion que para ello tienen" 245 . La sugerencia del servicio era ahora vista con otros ojos, habida cuenta del desastre de la Armada (la noticia había sido dada por el propio monarca a los procuradores convocados en Cortes en septiembre de $1588)^{246}$, y el conocimiento de los agobios financieros de la monarquía.

Si en abril Berrio instaba a la aceptación del servicio, en junio de ese mismo año de 1589 Per Afán de Ribera, corregidor de la ciudad de Toledo, detectaba un alboroto entre los moriscos similar al que hemos indicado para Ciudad Real en 1577. El corregidor realizó una averiguación sobre la implicación de dos granadinos importantes, Íñigo Fernández y su hijo el médico Luis de Guevara, en la propagación del rumor de la vuelta al Reino de Granada. Al parecer muchos moriscos habían desistido de sus tratos comerciales, disminuyendo la recaudación de la alcabala y generándose un apreciable estado de nerviosismo en la ciudad, puesto que Fernández y Guevara habían indicado "que su magestad a mandado que se tratase en su Consejo de Poblaçion que los moriscos que se sacaron del rreino de granada se bolbiesen a poblar al dicho rreino y que para esto se avian fecho tres o quatro consexos de poblaçion para tratar el particular", para lo que esperaban sólo la llegada de la cédula corres-

244. AHN, Consejos, leg. 53305, Madrid, 2-II-1589.

245. AGS, CC, leg. 2191, 7-IV-1589, «al señor Juan Vázquez».

246. A.W. LOvETT, «The vote of the Millones (1590)», Historical Journal, 30, I, 1987, pp. 1-20, y aquí, p. 3. 
pondiente ${ }^{247}$. Se les preguntó si habían hecho ya repartos del cobro para realizar el servicio, extremo que negaron rotundamente ${ }^{248}$. En su declaración, padre e hijo se contradicen puesto que no niegan la existencia de las negociaciones, aunque siempre minimizan su impacto indicando que nadie les tomaba en serio, ni siquiera los moriscos toledanos.

Luis de Guevara se defendía dejando entrever que la iniciativa venía de la Corte o al menos no de su parte. Según el médico, Juan Sánchez de Alarcón, escribano y "solicitador de los del reino de Granada" le había notificado que volverían a Granada algunos moriscos y se le comunicaba que se habían nombrado varios diputados para distintas zonas:

\begin{tabular}{ll}
\hline CIUDAD & DIPUTADOS \\
\hline Valladolid y Toledo & Miguel Hernández y Luis de Guevara \\
Sevilla & Alonso Fernández Camino y Lorenzo de Berrio \\
Granada y otros & Luis Castellanos y Salvador de Mendoza \\
Baeza & Arauz \\
Pastrana & Luis de Valdivia \\
\hline
\end{tabular}

Guevara declaraba haber estado en la corte con Luis Castellanos y Juan Sánchez tratando con el fiscal del rey Luis Pérez de Rueda y con el secretario de la Cámara Juan Vázquez de Salazar quien debía ser nombrado por diputado de cada zona. Aunque el tal Juan Sánchez propuso a Íñigo Fernández, el propio Guevara se postuló a sí mismo; finalmente ${ }^{249}$, Alarcón les avisó de que se había nombrado "a Lorençio de Verrio que fuesen a tomar poder y que nombraban por rezebtor a un Juan Perez escrivano publico que fue de Granada para que este escribano viniese a tomar poderes de los moriscos". Cada corregidor tendría que nombrar a ocho moriscos y estos elegirían a dos para dar los poderes.

Al declarar Íñigo Fernández, éste matizó a su hijo al indicar que no acudió a Madrid al no confiar en la pureza de la iniciativa aunque "Lorençio de Verrio que esta en Madrid le escrivio que fue alla y tiniendolo por burla no quiso yr". A Íñigo Fernández algunos testigos lo llaman "el jurado", y parece que fue nombrado en Granada en el año 1566 fiel y alcaide de campo por ausencia del alamín Diego Pérez y en el segundo cargo en sustitución de un tal Men-

247. AGS, CC, leg. 2189, para todo lo que sigue salvo otra indicación. En adelante, Información.

248. "Dixo que no paga tal ni darian blanca porque los demas dellos no quieren ir que les va muy bien asy".

249. En la proposición del servicio de 1579 todos los diputados son los mismos, incluidos Miguel Hernández y Luis de Guevara para Toledo. 
doza ${ }^{250}$; padre e hijo consideraban que habían sido elegidos "como jente mas principal della que aqui abia", y según un testigo a su favor, "Luis de Guevara decia que su padre Iñigo Hernandez era ydalgo e abia de ser comysario de este negoçio y el avia de ser el rrepartidor y el que nombrase las casas que abian de $\mathrm{yr}^{\prime \prime 251}$, indicando su procurador que padre e hijo eran "y siempre an sydo muy obedientes y servidores de la corona real como de los mas principales y nobles de los de aquel reino de granada y sus padres y hermanos y antepasados con ofiçios nobles y prinçipales" ${ }^{252}$. El mismo Guevara se definiría a sí mismo en el proceso inquisitorial abierto contra él en 1594 como "natural de la çiudad de Granada, vezino desta çiudad de Toledo... de parte de su padre desçendiente de los moros que entregaron el Reino de Granada a los Reyes Catholicos y por parte de su madre de christianos viejos" ${ }^{\prime 253}$.

En la información que el corregidor inició comparecieron de forma voluntaria dos moriscos mercaderes, Damián Partal y Miguel Hernández, a los que Î́nigo Fernández y su hijo denominaron como "enemigos capitales de sus partes" por motivos que luego veremos. No era para menos, puesto que estos moriscos aportaron a través de su procurador, Juan de Cuéllar, varios testigos que confirmaron la mayor parte de las acusaciones formuladas. En general los testigos acuerdan señalar la publicidad que padre e hijo dieron a la llegada de una copia de la cédula enviada al corregidor para nombrar a ocho personas encargadas del reparto, así como su nombramiento como responsables últimos, aunque no se ponían de acuerdo en cuantos moriscos dado que no lo concretaban exactamente "una vezes deçian çinco mil casas y otras bezes deçian seis mill casas, esto sirviendo a su magestad con grandisima cantidad de dinero... unas vezes dezian que con dozientos mill ducados y otras que treçientos mill ducados", señalando en alguna ocasión que se pagarían 50 ducados por cada casa ${ }^{254}$. Menos acuerdo mostraron en confirmar el abandono de los moriscos de su actividad económica, pues algunos señalan que les daban crédito, y otros que no se dejó de comerciar, si bien es cierto que los moriscos forasteros que traían mercancías sintieron una merma en los intercambios ${ }^{255}$.

Como respuesta, Luis de Guevara presentó una serie de testimonios destinados a demostrar cómo estas acusaciones se fundaban en la "pasion y malicia de los susodichos, procurando ocultar sus culpas", puesto que habían sido

250. R. Jiménez Vela, Índices de los libros de cabildo del Archivo Municipal de Granada, 1518 / 1566, Granada, Universidad de Granada, 1987, p. 362, jurando el cargo en 12-VII-1566, p. 363. No aparece en las nóminas de jurados publicadas por J.A. LÓPEZ NEVOT, op. cit., pp. 187-196, 202, n. 748.

251. Información, testimonio de Francisco de Molina.

252. Información, defensa de Lorenzo Rodríguez de Haro, procurador de Íñigo Fernández y Luis de Guevara.

253. J. SiERRA, Procesos en la Inquisición de Toledo (1575-1610). Manuscrito de Halle, Madrid, Trotta, 2005, p. 426 .

254. Información, Testimonios de Hernando de Rojas y de Felipe de Toledo.

255. Información, Testimonio de Bartolomé Rodríguez. 
Miguel Hernández y Damián Partal los verdaderos organizadores del servicio, y no ellos, acusando al primero de que "anduvo concitando la jente y les llevo muchos dellos a cada uno diez reales sobre la dicha buelta y trato della".

Lo cierto es que sólo uno de los testigos presentados por Guevara respondió a una de las preguntas del interrogatorio que no había contestado ningún testigo anterior: si sabían que Íñigo Fernández había estado preso en la cárcel de Granada "por el rebelión de los moriscos", nada menos. Y ello era cierto, puesto que su nombre figuraba junto al de otros señalados moriscos en una memoria sobre los pleitos abiertos para recuperar sus bienes, sostenidos por moriscos declarados inocentes pero altamente sospechosos de haber participado en la rebelión. Entre otros aparecían importantes mercaderes como Lorenzo Hernández el Chapiz y Hernán López el Ferí, avecindados en Pastra$\mathrm{na}^{256}$, y los sempiternos Lorenzo y Melchor de Berrio, todos ellos "ombres rricos de los naturales deste rreyno" 257. Así, el primer testigo presentado por Guevara, el mercader de sedas Andrés de Dueñas, corroboraba que Íñigo Hernández había estado "preso en Granada por el rebelion de los moriscos e que a oydo decir que el dicho Luis de Guebara juro contra su padre e que save que de los dichos quatro meses a esta parte el dicho Iñigo Hernandez dixo muchas vezes que dios abia querido que este negoçio se biniese a efetuar por sus manos y que ya hera llegada la ora de dios", frase que también recordaba el testigo de Damián Partal, Jerónimo de Mendoza.

Tras la declaración de los testigos, el procurador de Íñigo Fernández y Luis de Guevara reveló que Miguel Hernández y Damián Partal habían traído testigos contra los anteriores porque éstos les habían denunciado "sobre el traer de las armas no las pudiendo traer e sobre aver husado de una ejecutoria de hidalguía y armas siendo como es falsa", usando ejecutorias falsas los testigos Hernando de Rojas y Jerónimo de Mendoza, dando poco crédito a sus acusaciones habida cuenta de que el testigo Bartolomé Rodríguez era sobrino de Partal ${ }^{258}$. Terminaba diciendo que el mostrar cartas no era delito, que estaban firmadas por el solicitador Alarcón y nada más, y aunque a Íñigo Hernández se le invitó a ser el principal comisario del repartimiento, no aceptó ${ }^{259}$. Si como parece los comisarios diputados para organizar el cobro y la vuelta eran Miguel Hernández e Íñigo Fernández, más bien parece que se dio una disputa entre

256. Sobre estos mercaderes, A. GARCíA LÓPEZ, Señores, seda y...

257. AGS, CC, leg. 2206, Memoria de los pleytos que estan ante Pedro de la fuente que tocan pidir su hazienda por dezir que son libres y sin culpa en la rrebelion de los moriscos", vid., M.F. FERNÁNDEZ CHAVES, op. cit.

258. Y era cierto que los granadinos Damián Partal, Luis Redondo, Miguel Núñez, Diego de Escobar y Luis de Herrera se quejaban ante la Cámara en agosto de 1579 porque el corregidor de Toledo, Per Afán de Ribera, no les había dejado portar armas, cuando ellos declaraban gozar de ejecutorias que les habilitaban para ello aprobadas por el Consejo de Población, AGS, CC, leg. 2191.

259. Información, defensa de Lorenzo Rodríguez de Haro, procurador de Íñigo Fernández y Luis de Guevara. 
estos notables por algún problema entre ellos. Desde luego el asunto no parecía tan maduro como pudiera pensarse, a la luz de las cartas que se le requisaron a Hernández. En la primera de ellas, fechada el 21 de mayo ${ }^{260}$, Alarcón informa excitado a Guevara que "ya llego la hora de dios" puesto que en el último consejo "el negocio se cometio al señor Juan Vazquez y al señor fiscal", por lo que solicitaba a Guevara que acudiese presto a la Corte, dado que quería comenzar a negociar con él presente y con Bernardino Sánchez vecino de Pastrana. En la segunda carta enviada a Guevara, fechada una semana después, el solicitador Alarcón informa al licenciado Guevara que había conseguido real cédula "para que todos den poder al señor Yñigo el jurado y Bernardino Sanchez por ante Juan Perez escribano, para este asiento", invitando también a venir a Madrid al primero "y todo ba como yo lo he deseado gloria a dios. Al señor Iñigo el jurado beso las manos". Se conservan las copias de estas cédulas dirigidas a distintas autoridades donde los moriscos constituían una población apreciable ${ }^{261}$. Tras ello, informaba a su interlocutor de un dato esencial: "El señor don Alonso ${ }^{262}$ a enviado a llamar a Berrio. Tarde bendra, que ya hemos negosiado syn el, porque si viniera mi rrindira como las otras vezes que abia nombrado, mas aca estando de punta contra el sy no se hallara, el señor fiscal a querido dar a Juan Perez que pasen ante el los poderes. [El] negoçio va de veras". La lectura de estas misivas dejan claro que en 1589 Lorenzo de Berrio formaba parte importante del proyecto del servicio, pero que también existía cierta animadversión en cuanto a su protagonismo, pasando la responsabilidad al escribano de Granada Juan Pérez y como eje principal de las negociaciones, a Íñigo Fernández y Bernardino Sánchez.

Aún más sorprendente es la siguiente frase de la carta en la que se asegura a Guevara esto: "Un decreto dize buelban los leales del rreyno todo" añadiendo en seguida, "Algunos les pareze que todos". Alarcón indicaba que despachaba con Juan Vázquez de Salazar y el fiscal para conocer a fondo las "calidades" de los que acudían a negociar a Madrid, considerados por Alarcón como "cavezas de rreino y cavalleros e con sus criados y factores goviernan sus haçiendas y ellos se estan en su casa aguardando el nombramyento de su magestad".

Pero las cosas se torcieron en Madrid, puesto que a seis de junio Guevara todavía estaba en Toledo y recibía ahora noticias que reclamaban prudencia,

260. Todas estas cartas se encuentran copiadas al final de la información ya citada.

261. AHN, Consejos, leg. 53305. Es muy importante constatar cómo la división del territorio que seguían las cédulas no se correspondía con la que los moriscos hacían por comisionados. Así se escribieron cédulas para los corregidores de Córdoba, Jaén y Andújar, Salamanca, Úbeda y Baeza, Ciudad Real, Valladolid, Alcalá de Henares, Sevilla y Toledo, así como para el gobernador del partido de Almagro, el de la Orden de Calatrava, de la Orden de Santiago en el Partido de Ocaña. Ya en el nuevo servicio de 1597 los 18 partidos se corresponden con las 18 ciudades en Cortes, correlación ésta que no pasó desapercibida para B. VINCENT, «Los moriscos granadinos...», p. 173.

262. Seguramente se trata de don Alonso Granada Venegas. 
rogando Alarcón que "vuestra merced me haga merced de no hazer mandamiento desa ciudad ni benyr a esta corte hasta que yo ynbie la zedula rreal a su padre de vuestra merced que importa azertar el negocio y mi honrra tambien y si vuestra merced biene diran en Toledo que bino a que lo nombrasen y esto se haga e rescibire merced aunque le escriva el señor Berrio... Si el señor Berrio le escribiere bien se que le sabra vuestra merced responder entre ello le diga vuestra boluntad...". Una vez enviada esta carta, parece que Alarcón quiso dejar muy claro que el desmarcaje de Berrio no era sólo cosa suya, sino que Guevara y su padre tenían que apoyarle. Para ello les envió otra el mismo día aclarando algunos puntos: "Vuestra merced sabra que an pasado aca tantas cosas que no son para decir en cartas mas de que el señor Lorenzo de Berrio a dado a entender que dize... que el señor Yñigo Hernandez no a de estar en este negocio... que queriendo acabar este negocio me dixo el a mi que pues tanto queria que fuese Yñigo el jurado que no fue jurado syno su hermano y que fuese el el otro... y queriendolo hazer ambos de conformidad dixo «señor deshacer lo que esta hecho si pudiere» bien ve como le dije que no se podia tratar contra el e ansi me fuy de alli. Juan Perez quedo riñendo con el...". Así pues, Lorenzo de Berrio tenía el peso suficiente para que su opinión sobre tan grave asunto fuera determinante, y para negociar directamente con el solicitador en la Corte y el escribano Juan Pérez. Un día antes de la redacción de estas dos cartas Lorenzo de Berrio había solicitado de la Corona libertad de movimientos para poder desplazarse junto a Juan Pérez para poder concertar el asiento en las diversas localidades donde debía negociarse, obteniendo la autorización de la Corona $^{263}$. Con ello se alejaban las posibilidades de liderar el proyecto del servicio por parte de Íñigo Hernández y su hijo el licenciado Guevara.

Estas cartas muestran a Lorenzo de Berrio como un duro negociante que sin embargo no tiene el respaldo de todos los moriscos. En la siguiente carta, fechada a 10 de junio, Alarcón indica a Guevara que Lorenzo de Berrio estuvo en Pastrana como antes había pasado por Toledo, y que los moriscos de Pastrana hablaron a través de Luis de Valdivia quien "bino... por todos a rresponder a Berrio y le dixo que los de Pastrana no querian dar aquel poder ni yr a Granada por aquella horden y otras cosas". No obstante, parece que el proceso seguía adelante, puesto que Alarcón se hace eco de la llegada de la orden a los corregidores para nombrar a ocho moriscos principales. Sin embargo, el "negocio" estaba aún lejos de concretarse, puesto que justo en esos días un documento enviado al rey indicaba que era mejor dar largas al proceso, puesto que para los intereses de la monarquía era más importante y cuantioso el servicio de los ocho millones, por lo que se esperaba primero a su resolución, "estando lo de los ocho millones en el estado que está y habiendose de tratar como vuestra merced sabe de la prorrogación del encabezamiento de aqui a algunos dias por acabarse la que agora corre en fin deste año, no sabe su magestad si para lo uno, y para lo otro ha de

263. AGS, CC, leg. 2191. Madrid, 5-VI-1589. 
embarazar esto de los moriscos y hacer mas ruido del que convendría, y así manda se vea lo dicho en la junta donde se trata de ello y se le avise..."264.

La última carta que el corregidor Per Afán de Ribera intervino al licenciado Guevara databa del 12 de junio. Alarcón enviaba adjunta una copia de una misiva dada "por la horden que Lorençio de Berrio dio que a mi juicio no puede ser mejor". Aunque Alarcón se confiaba con que Toledo y Pastrana estuvieran de acuerdo, mostraba la desconfianza de muchos dado que "yendo el poder como va nadie querra obligarse por nadie", quedando además pendiente la negociacón con Alcalá de Henares, Valladolid y Salamanca, aunque confiaba plenamente en Berrio: "este hombre es muy mañoso y podra ser que hazerse le otorguen el poder a el y a quien el quisiere y como vuestra merçed por la cabeza no an de ser mas de dos sera el uno y otro quien el quisiere". Por lo tanto, aunque existiesen discrepancias con Lorenzo de Berrio ${ }^{265}$, parece claro que se sentía la necesidad de contar con su participación para poder aunar voluntades, puesto que había moriscos "principales" de ciudades importantes que no se habían sumado al poder para realizar la negociación en nombre de todos. Lo áspero de las negociaciones quedaba contenido en una carta que enviaban los comisarios del repartimiento "nombrados por çedulas de vuestra magestad" en la que pedían la concesión de franquezas como cristianos viejos que se resumían en la libertad de movimientos, la posibilidad de regresar al Reino de Granada y poder portar armas. Se quejaban de que este servicio al rey les suponía el desplazamiento fuera de sus hogares y la enemiga de muchos moriscos y cristianos viejos: "hallando las dificultades que se ofrecian para las dichas cobranzas y adquiriendo el dicho servicio muchas personas de los dichos naturales que no estavan alistados por las justicias del Reino por no tener conoscimiento dellos y como nosotros conosçiamos generalmente a todos los naturales del dicho Reino y les avemos alistado y repartido y cobrado dellos lo que justamente devian pagar con los quales hemos quedado osiossos y enemistados y lo propio con otras muchas personas cristianos viejos por no haber condecendido con sus ruegos en no reservar personas a quien pretendian favorescer para que no pagasen"; estas peticiones no fueron atendidas ${ }^{266}$.

\section{DE LA FIDELIDAD AL SERVICIO}

Durante toda su vida fuera de Granada, Lorenzo de Berrio aparece como interlocutor esencial en la creación del servicio de los moriscos, que tiene como base fundamental el deterioro dramático de la hacienda del rey y la capaci-

264. AHN, leg. 53305. San Lorenzo del Escorial, 13-VI-1589.

265. Habla también de "lo que convenga con todo heso me olgare de saver que hesos dos hidalgos que binieron aqui dizen de my y de este negoçio porque aca delante Lorençio de Berrio hecharonse con la carga contra el podra ser halla aberles parecido otra cosa".

266. AGS, CC, leg. 2191, s.f. aunque lo atribuimos a 1589 ó 1590. 
dad de Berrio y otros consortes para movilizar a los moriscos desterrados para contribuir en la fiscalidad del reino, reeditando la desigualdad impositiva de la que fueron protagonistas a través de la farda, ahora en Castilla. Y como sabemos, Berrio fue uno de los máximos sospechosos de haber participado o al menos haber contribuido en la rebelión de 1568. Otros moriscos que obedecían al mismo perfil como los Ferí o el Chapiz, también entraron en el "negocio" del servicio, e incluso uno que no se dedicaba a la actividad mercantil como Íñigo Hernández, también participó en la propuesta del servicio. La fidelidad se recompraba, aunque no fuera genuina. Tal sucedió con el licenciado Guevara, quien con cuarenta años fue encausado por la Inquisición de Toledo en 1594, dado que entre otras cosas se testificó que le "bieron tañer y cantar al dicho Guevara con otros moriscos y leer llorando en un libro que estando Nuestra Señora en dias de parir se fue al desierto y dandole un dolor dio una buelta a un arbol seco y reberdecio y dandole otra buelta floreçio y dandole otra buelta pario... y que queriendo los paganos detener a Christo se abia huido... y cruçifixado a otro que se le pareçia... tenia mucha amistad con unos moriscos que entendia se avian pasado a Berberia y que leya en un libro arabigo y dezia que era en latin... y que... dixo a çierta persona quel le daria un abrazo para que no le pudiesen prender...", además de ser acusado de ayunar el Ramadán y otras cosas. Lo negó todo, aunque al final confesó que había aprendido la "ley de los moros", el Corán y las cuatro oraciones, el guadoc, la zala y el ayuno y que había practicado el islam "creyendo salvarse en ella". Fue condenado a salir en el auto, "reconçiliaçion, abito y carcel perpetua, con confiscacion de bienes en forma" ${ }^{267}$. Pero no es el único caso, pues como hemos visto un hijo de Lorenzo de Berrio fue también perseguido por la Inquisición debido al manejo de un Corán y el conocimiento de la lengua árabe. La cuestión no queda aquí, puesto que entre 1601 y 1603, otro morisco granadino encausado por el tribunal de Toledo, Jerónimo de Rojas, recordará el caso de Guevara como uno de los que no habían delatado a sus correligionarios, por lo que recibió una ayuda de otros moriscos de 200 ducados. Aún más, tanto Rojas como Guevara eran amigos del famoso traductor de los plomos del Sacromonte y médico morisco Miguel de Luna, considerando Rojas que en su tiempo Guevara "trabó con él grande amistad y trataron juntos muchas cosas muy hondas de la secta porque no hay en España mejor moro que el dicho Luna, y que aunque el dicho Guevara sabe de la secta, no sabe tanto" ${ }^{268}$. Luna tenía contacto con un mercader morisco que Rojas no nombra, e indicaba que "el licenciado Luna les declaró cómo en las hojas de plomo que se han hallado en el Monte Santo de Granada está escripto de mano de Jesucristo cómo el mismo dixo que ni era Dios ni hijo

267. J. SIERRA, op. cit., pp. 426-427.

268. La novedosa noticia por la que se relaciona a Miguel de Luna con el más vigoroso criptoislam español ha sido puesta de manifiesto recientemente en el libro fundamental de M. GARCÍA-ARENAL y F. RodRígUEZ MEDIANO, op. cit., pp. 192-195. El proceso de Rojas aparece también resumido en las actas de Halle, cfr. J. SIERRA, op. cit., p. 515. 
de Dios ni dios tenía hijo, que no se engañasse nadie, y que en el día del juicio los miserables christianos engañados, quando se vean condenar... éste se descartará diciendo en ninguna parte está escripto que él dixesse que era hijo de Dios sino que ellos con su latín y en sus concilios lo han venido a decir..." ${ }^{269}$. Para Rojas, Guevara había aprendido de dos "ausentes que estaban en salvo en Berberia, que eran dos hermanos, uno aceytero y otro tratante de seda, de los quales el dicho Guebara habia aprendido la secta, que vivian frontero de su casa" y aunque era un buen moro, "no save tanto como su padre"270.

Existe pues, una conexión muy sutil entre una serie de elementos capitales en esta segunda parte de la historia de los moriscos:

1. El sostenimiento de la lengua árabe como elemento identitario teñido de una mayor o menor carga islámica ${ }^{271}$.

2. El protagonismo de los próceres moriscos encargados del servicio.

3. La constante sospecha de su participación en la rebelión de Navidad de 1568.

4. La "invención y tesoro" ${ }^{272}$ de los plomos del Sacromonte.

5. La división entre los deportados entre "leales" y "traidores" ${ }^{273}$, base del servicio.

Éstos eran los elementos independientes pero combinables de una estrategia de legitimación del valor político de estas nuevas élites que construían su prestigio y su papel rector de la minoría en base a ellos. Los “agentes de la reconstrucción” de la nación morisca fueron en gran medida mercaderes oriundos del Albaicín, siempre sospechosos de haber participado en la rebelión cuya responsabilidad habrían evitado en el último momento ${ }^{274}$. Lorenzo de Berrio ocupó en este proceso un papel capital que todavía debe reconstruirse poniendo en valor las relaciones de este morisco con otros de sus correligionarios. La ejemplar red tejida por Lorenzo de Berrio tenía en la ciudad de Sevilla su retaguardia y uno de sus fundamentos, aunque la naturaleza de la actividad

269. M. García-Arenal y F. Rodríguez Mediano, op. cit., pp. 192-193. Similares proposiciones eran las que sostenía (entre otras) el propio Jerónimo de Rojas, cfr. AHN, I, leg. 197, exp. 5.

270. AHN, (I)nquisición, leg. 197, expte. 5.

271. Sobre el valor de la lengua árabe, de nuevo es fundamental M. GARCíA-ARENAL y F. RoDRíGUEZ MEDIANO, op. cit., especialmente los capítulos 2 y 4-7.

272. Sobre los cuales es de indispensable consulta M. BARrios Aguilera y M. GARCÍA-ARENAL (eds.), Los plomos del Sacromonte. Invención y tesoro, Valencia, Universidades de Valencia, Granada y Zaragoza, 2008.

273. Que aparece en otros ámbitos como las cartas de Alonso Granada Venegas enviadas al rey y al inquisidor general, y en el pensamiento de Alonso del Castillo o Miguel de Luna, véase M. García-Arenal y F. Rodríguez Mediano, op. cit., pp. 91, 98, 121 y 175.

274. Como indica Mármol en el momento en que Farax Aben Farax no tuvo respuesta a su llamada entre los albaicineros cuando se encontraba en el barrio: siendo respondido "Hermanos, idos con Dios; que sois pocos y venis sin tiempo", L. DEL MÁrmol CARvajAL, Historia del Rebelión y Castigo de los moriscos del Reino de Granada, Málaga, Arguval, 1991, pp. 90-91. 
económica de los Berrio en la ciudad no esté todavía tan clara como la de otros moriscos de Toledo o Pastrana, dedicados de manera manifiesta a la fabricación y trato de la seda, así como a la especiería. Por su importancia económica, la ciudad de Sevilla congregó un alto número de moriscos, y quizás la proximidad con Berbería también le dio valor dentro de la geografía morisca peninsular. Por ella pasaron muchos cristianos nuevos, como el propio Jerónimo de Rojas que veíamos antes, cuya hermana estaba casada con un morisco herrero de la ciudad, o el mismo Miguel de Luna ${ }^{275}$.

El servicio funcionó como un nuevo método de negociación con la Corona, en el que las máximas aspiraciones de los moriscos no se cumplieron. Así, aún en 1592 Lorenzo de Berrio solicitaba una mayor movilidad para los moriscos ${ }^{276}$, y al año siguiente el agente de los naturales del Reino de Granada, Juan Pérez, que había estado encargado de coordinar el servicio, abundaba en esta petición solicitando además un mejor trato judicial para los moriscos, puesto que "les hazen causas ansi por el vivir juntos como por el algaravia no hablandola y demas desto por andar sin pasaportes y por yrse a vivir por fuera de sus aloxamientos que la nezesidad les costriñe y los malos tratamientos porque van a ganar de comer por no poderse sustentar donde estan y les llevan las justicias sus haziendas en condenaciones y costas que les hazen y no los quieren oyr y tanbien siendo servicio vuestra magestad de hazerles merced que se trate lo de la buelta a Granada algunas cassas"277. Estas cuestiones ponen finalmente de manifiesto el carácter precario y contradictorio de los progresos políticos de la minoría morisca, no conllevando en definitiva la concesión del servicio muchas de las perseguidas y anheladas contrapartidas. En el caso de los Berrio, la debilidad de los logros se pone de manifiesto en el hecho de que en 1594-1595 sigamos hallando a Lorenzo de Berrio enfrascado en un pleito sobre "su descendencia y filiacion" 278 , en el que se volvieron a poner sobre la mesa y a valorar las acusaciones de haber sido culpados en la rebelión de los moriscos de Granada, de haber sido sacados según los bandos, y deliberándose sobre "sus personas y reputacion". Además, "en lo que toca a sus hijos, no ay quien se acuerde dellos ni los conozca", en referencia a su carácter gris en comparación con una figura tan destacada como la de Lorenzo de Berrio. A fines de 1595 proseguían las informaciones en Granada, Sevilla y Baeza sobre Lorenzo y Melchor de Berrio, así como sobre Juan Pérez de Berrio y Luis de Berrio $^{279}$. A pesar del indudable papel jugado por Lorenzo de Berrio en el esta-

275. Después de enviudar su hermana había marchado a Sevilla, donde él pasó unos días en 1601. AHN, I, leg. 197, expte. 5. Miguel de Luna fue enviado junto al licenciado Pedro Guerra de Lorca para mostrar a Benito Arias Montano un informe sobre el pergamino de la Torre Turpiana y las reliquias sacromontanas en 1593 (M. GARCíA-ARENAL y F. RodríGUEZ MEdiAnO, op. cit., p. 179).

276. AGS, (C)onsejo y (J)untas de (H)acienda, leg. 292, expte. 28. 15-XI-1592.

277. AHN, Consejos, leg. 53305. 14-XII-1593.

278. AGS, CC, leg. 2191.

279. AGS, CC, leg. 2198. 
blecimiento del beneficioso (para la Corona) servicio de los naturales del Reino de Granada, estaba claro que el rey no olvidaba lo pasado, y que no daría nunca el paso hacia una vuelta "real" a los tiempos granadinos del pacto fiscal.

\title{
RESUMEN
}

A partir de un estudio del caso que analiza la trayectoria de los hermanos moriscos Berrio, se profundiza en el papel jugado por los capitalistas moriscos anteriores a la guerra de Granada en la negociación política que tuvo lugar en las décadas siguientes al conflicto, y en los procesos de transformación de la comunidad que estuvieron aparejados a ellos.

Palabras clave: hermanos Berrio, capital morisco, negociación política, historia de los moriscos.

\begin{abstract}
In this paper the authors analyze the particular case of the Berrio morisco brothers in order to understand the role played by the morisco capitalists in the transformation experimented by the morisco community before 1568-1571 Granadas' war and in its subsequent aftermath, stressing the study in their political negotiation that they impulsed with the crown after the war.
\end{abstract}

Key words: Berrio brothers, morisco capital, political negociation, Moriscos' History. 